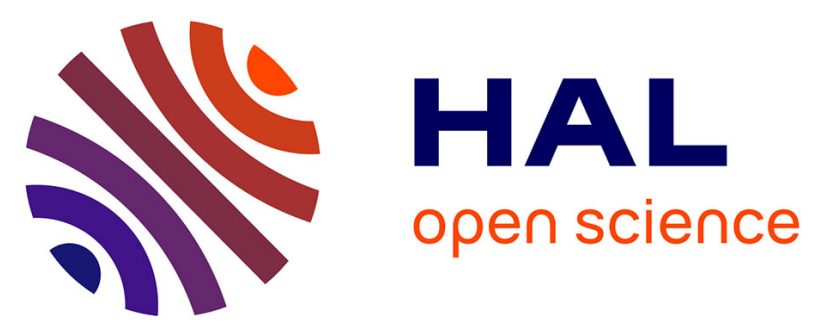

\title{
Submarine lava flow emplacement and faulting in the axial valley of two morphologically distinct spreading segments of the Mariana back-arc basin from Wadatsumi side-scan sonar images
}

Miho Asada, Anne Deschamps, Toshiya Fujiwara, Yasuyuki Nakamura

\section{To cite this version:}

Miho Asada, Anne Deschamps, Toshiya Fujiwara, Yasuyuki Nakamura. Submarine lava flow emplacement and faulting in the axial valley of two morphologically distinct spreading segments of the Mariana back-arc basin from Wadatsumi side-scan sonar images. Geochemistry, Geophysics, Geosystems, 2007, 8, pp.Q04001. 10.1029/2006GC001418 . insu-00238519

\section{HAL Id: insu-00238519 \\ https://hal-insu.archives-ouvertes.fr/insu-00238519}

Submitted on 15 Feb 2011

HAL is a multi-disciplinary open access archive for the deposit and dissemination of scientific research documents, whether they are published or not. The documents may come from teaching and research institutions in France or abroad, or from public or private research centers.
L'archive ouverte pluridisciplinaire HAL, est destinée au dépôt et à la diffusion de documents scientifiques de niveau recherche, publiés ou non, émanant des établissements d'enseignement et de recherche français ou étrangers, des laboratoires publics ou privés. 
Click

Here

Full

Article

\title{
Submarine lava flow emplacement and faulting in the axial valley of two morphologically distinct spreading segments of the Mariana back-arc basin from Wadatsumi side-scan sonar images
}

\author{
Miho Asada \\ Department of Ocean Floor Geoscience, Ocean Research Institute, University of Tokyo, 1-15-1 Minamidai, Nakano-ku, \\ Tokyo 164-8639, Japan (asada@ori.u-tokyo.ac.jp)
}

\section{Anne Deschamps}

UMR 6538 "Domaines Océaniques," UBO-CNRS Institut Universitaire Européen de la Mer, Technopole Brest Iroise, Place N. Copernic, F-29280 Plouzané, France (anne.deschamps@univ-brest.fr)

\section{Toshiya Fujiwara}

Institute for Research on Earth Evolution, Japan Agency for Marine-Earth Science and Technology, Natsushima 2-15, Yokosuka, Kanagawa 237-0061, Japan (toshi@jamstec.go.jp)

\section{Yasuyuki Nakamura \\ Department of Ocean Floor Geoscience, Ocean Research Institute, University of Tokyo, 1-15-1 Minamidai, Nakano-ku, Tokyo 164-8639, Japan (saru@ori.u-tokyo.ac.jp)}

[1] High-resolution, deep-tow side-scan sonar data were collected over two distinct spreading segments in the central part of the Mariana back-arc basin. These data allow mapping of small fissures and faults and the distinguishing of hummocky from smooth lava flows. Using these data, we observe spatial variations in seafloor deformation and volcanic activity within each segment, and also significant differences in the degree of tectonic deformation between the two segments. One segment, characterized by an hourglass shape suggestive of magmatic processes dominating over tectonic processes, is in fact currently dominated by intense deformation rather than volcanism. The other segment, which exhibits morphology (wide and deep linear axial valley) typical of magma-starved segments, is subjected to very limited deformation and is covered by mostly unfaulted, recent flows. Each segment also displays along-axis variations in the degree of tectonic deformation and in lava flows freshness. We observe a decrease of lava effusion rate from segment centers toward their ends. We also investigated the apparent asymmetry of the Mariana basin. On the southern segment of the study area, azimuths of tectonic structures are divided into two groups, one segment-parallel and one $\sim 15^{\circ}$ oblique to strike of the segment. These two trends of linear features developed synchronously with volcanic activity. Currently oblique structures seem to be the most active ones. The tectonic structures that are parallel to the overall valley trend are distributed over the entire valley, whereas the oblique structures are only located proximal to the eastern valley wall. They are likely related to changes in the local stress field related to the obliquely trending eastern axial valley wall. Asymmetric character, such as nonuniform spacing and throw of faults, was not observed. These observations suggest that the asymmetry of the basin is not due to asymmetric spreading, but rather to eastward ridge jumps of several kilometers. Such small-amplitude ridge jumps likely occurred frequently during basin development because the asymmetric character of the basin is strongly pronounced and no abandoned rift valley is recognizable within the entire basin. 
Components: 9923 words, 13 figures.

Keywords: back-arc; deep tow; side-scan sonar; phase bathymetry; volcanism; asymmetry.

Index Terms: 3035 Marine Geology and Geophysics: Midocean ridge processes; 8414 Volcanology: Eruption mechanisms and flow emplacement; 8010 Structural Geology: Fractures and faults.

Received 10 July 2006; Revised 13 November 2006; Accepted 4 January 2007; Published 3 April 2007.

Asada, M., A. Deschamps, T. Fujiwara, and Y. Nakamura (2007), Submarine lava flow emplacement and faulting in the axial valley of two morphologically distinct spreading segments of the Mariana back-arc basin from Wadatsumi side-scan sonar images, Geochem. Geophys. Geosyst., 8, Q04001, doi:10.1029/2006GC001418.

\section{Introduction}

[2] The Mariana back-arc basin is bounded to the east and west by the active Mariana volcanic arc and the West Mariana Ridge, respectively. It exhibits a characteristic bow shape. The basin lies at the southeastern edge of the Philippine Sea Plate and is currently developing behind the Mariana Trench where the Pacific Plate subducts beneath the Philippine Sea Plate (Figure 1). The spreading rate in the basin ranges from 20 to $40 \mathrm{~mm} / \mathrm{yr}$ (full rate), and is fastest in the southern portion of the basin [Kato et al., 2003]. The locus of active extension is not located at the center, but rather on the eastern side of the basin, indicating asymmetric seafloor accretion.

[3] Most active and extinct back-arc basins worldwide display varying degrees of asymmetric topography. Asymmetry in the Mariana Basin is obvious from surface bathymetry and magnetic anomaly data [Karig, 1971; Hussong and Uyeda, 1982; Bibee et al., 1980; Fryer, 1996; Yamazaki et al., 1993, 2003; Deschamps and Fujiwara, 2003; Deschamps et al., 2005]. Recently acquired magnetic anomaly data suggest that asymmetric seafloor extension in the Mariana Basin likely began during the back-arc rifting stage [Yamazaki et al., 1993, 2003], continuing into the current spreading stage [Iwamoto et al., 2002; Deschamps and Fujiwara, 2003].

[4] Either ridge jumps or ridge migration are likely responsible for asymmetric spreading in the Mariana Basin. Ridge jumps are intermittent positional changes of a spreading axis, while ridge migration is continuous and asymmetric accretion of seafloor along a spreading axis. To better constrain the processes responsible for the observed asymmetric structure of the Mariana Basin, as well as for the extent of variation in volcanic/ tectonic deformation in the back-arc setting, the first deep-towed side-scan sonar survey of the central Mariana Basin was conducted during the MICROMAR (microbathymetry on the Mariana spreading ridge) cruise in 2003. The "Wadatsumi" side-scan sonar system was utilized to survey two distinct, mature spreading segments along the central Mariana Basin, revealing details of lava flow morphology and tectonic patterns within the axial valleys.

[5] During preliminary analysis of a single segment, spatial variations in lava flow morphology and in tectonic deformation were detected, and a model was proposed that explains both the apparent change in the local stress field and the development of differently trending structures within the axial valley [Deschamps et al., 2005]. Here, we expand upon this model by first presenting a morphological analysis of the second surveyed segment, and then discussing results of morphological and statistical studies of the fissures, faults, and volcanic products within both segments. Ultimately, we propose that a "ridge jump" was a key factor in forming a highly asymmetric basin floor.

\section{Background}

\subsection{Plate Kinematics}

[6] Recent bathymetric and geophysical mapping of almost the entire area [Seama et al., 2002; Iwamoto et al., 2002; Kitada et al., 2006] has facilitated detailed discussion of spreading processes in the Mariana Basin, although estimates of spreading rate and history vary somewhat among previous studies. On the basis of geomagnetic anomaly data obtained during Deep Sea Drilling Project (DSDP) Leg 60, Hussong and Uyeda [1982] first suggested that rifting started at $\sim 6.5 \mathrm{Ma}$ with an average rate of seafloor spreading 


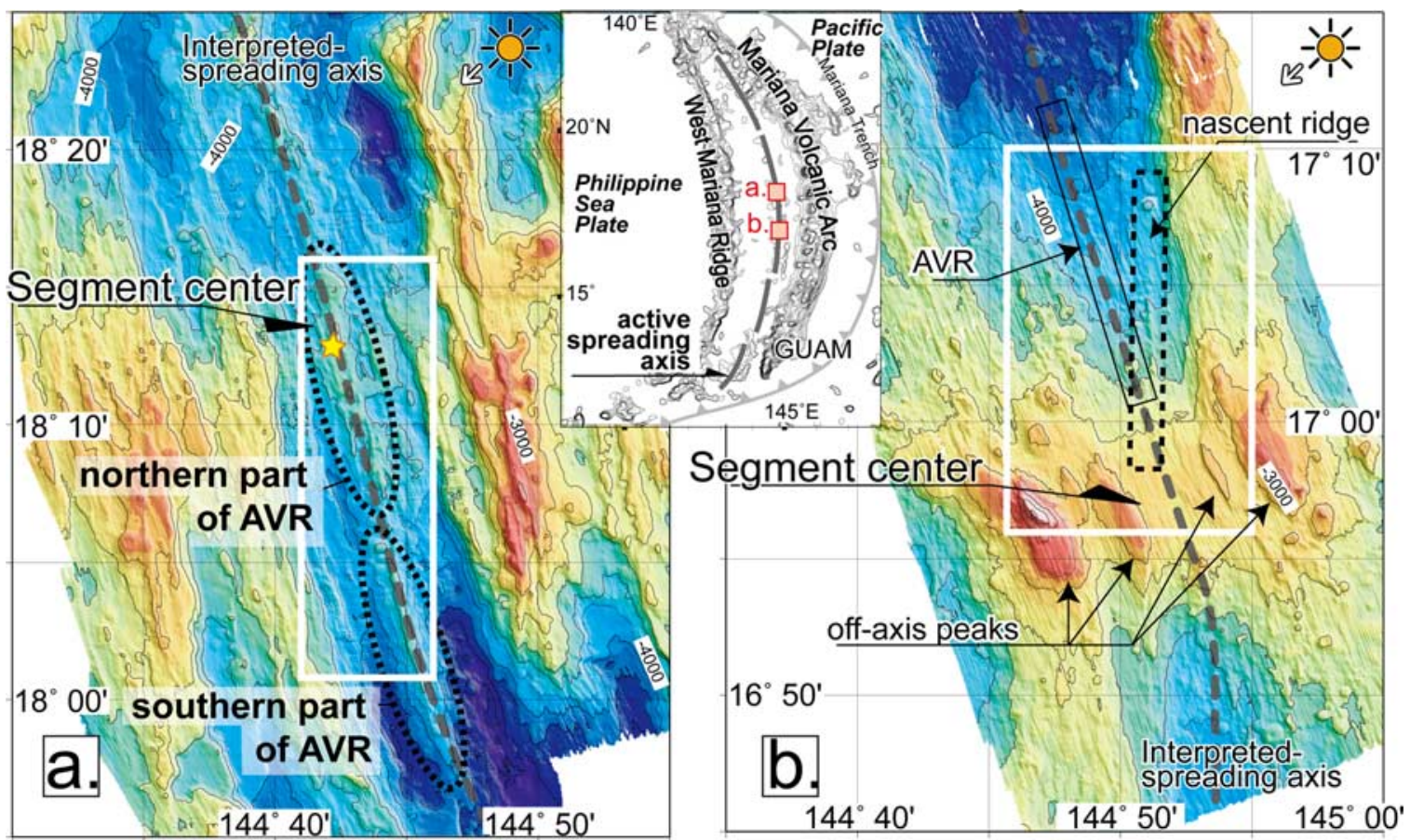

Figure 1. Index map of the Mariana Basin. Inset at top is a rough index image of the Mariana Basin. Marked areas a and $\mathrm{b}$ indicate the detailed studied area shown in Figures $1 \mathrm{a}$ and $1 \mathrm{~b}$ and discussed in this paper. Bathymetry data for the index map is ETOPO2 [Smith and Sandwell, 1997]. (a) Bathymetry of segment located at 18 $\mathrm{N}$ ("Seg-18"). Data are collected by hull-mounted multibeam system. The gray dotted line indicates the interpreted-spreading axis. The white box corresponds to the area surveyed by Wadatsumi (Figures $2 \mathrm{a}$ and $2 \mathrm{~b}$ ). Note that an axial volcanic ridge (AVR) is developed on the axial valley floor and is divided into two parts (black doted circles) based on its width and height. (b) Bathymetry of segment located at $17^{\circ} \mathrm{N}$ ("Seg-17"). Gray dotted line and white box indicate the interpreted-segment center and the Wadatsumi surveyed area (Figures 3a-3c), respectively. Note that the axial valley floor is flatter than at Seg-18, and AVR along interpreted axis (box enclosed by black solid line) has a reduced height than AVR in Seg-18. The $\sim 15^{\circ}$ oblique nascent ridge is developed from segment center to the foot of the eastern valley wall (dotted box).

$\leq 43 \mathrm{~mm} / \mathrm{yr}$ (full rate) over the past 5 million years. Iwamoto et al. [2002] subsequently refined this estimate with compiled magnetic anomaly data from the central Mariana Basin that indicates spreading started at $\sim 6.3 \mathrm{Ma}$ and remained relatively constant at a full rate of $\sim 30 \mathrm{~mm} / \mathrm{yr}$. Using the same data set, Deschamps and Fujiwara [2003] suggested a full spreading rate of $\sim 33 \mathrm{~mm} / \mathrm{yr}$ since 0.78 Ma. Recent Global Positioning System (GPS) data, indicating an opening rate of $20-40 \mathrm{~mm} / \mathrm{yr}$, indicate that the southern part of the basin is opening faster than the northern part [Kato et al., 2003]. These GPS data also revealed that the direction of displacement, relative to the Philippine Sea Plate, of the active Mariana Arc islands in the central part of the basin ranges between $\mathrm{N} 70^{\circ} \mathrm{E}$ and $\mathrm{N} 75^{\circ} \mathrm{E}$ [Kato et al., 2003]. The off-axis, NNW-SSE trending abyssal hills [Iwamoto et al., 2002] are consistent with the calculated spreading directions [Seama et al., 2002].

\subsection{Large-Scale Morphology of the Two Surveyed Segments}

[7] The spreading segments in the central Mariana Basin exhibit topographic features typical of slowspreading ridges [Macdonald et al., 1988], either clear axial valleys and axial volcanic ridges (AVRs), or bathymetric highs that indicate focused magmatism at segment centers [e.g., Bibee et al., 1980]. The two spreading segments surveyed during the MICROMAR cruise display contrasting topographic characters. They are separated by a $70^{\circ} \mathrm{E}$ trending large transform fault at $\sim 17.5^{\circ} \mathrm{N}$ that cuts across the entire basin.

[8] One of the surveyed segments, referred to herein as "Seg-18", lies between $17^{\circ} 50^{\prime} \mathrm{N}$ and $18^{\circ} 40^{\prime} \mathrm{N}$ (Figure 1a) and displays steep walls, a linear axial valley $\leq 9 \mathrm{~km}$ wide, and a prominent AVR located in the middle of the valley [e.g., Deschamps and Fujiwara, 2003]. The other seg- 


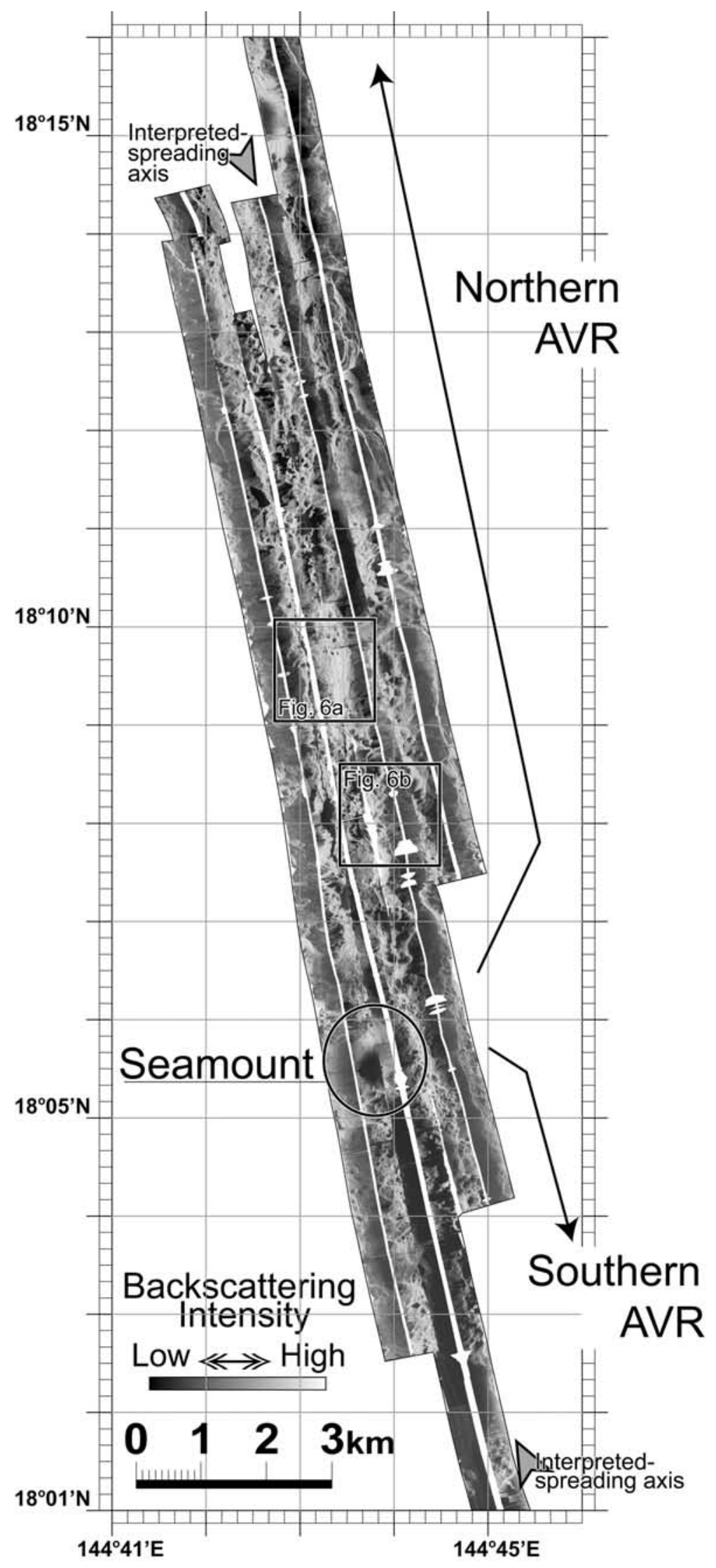

Figure 2a 

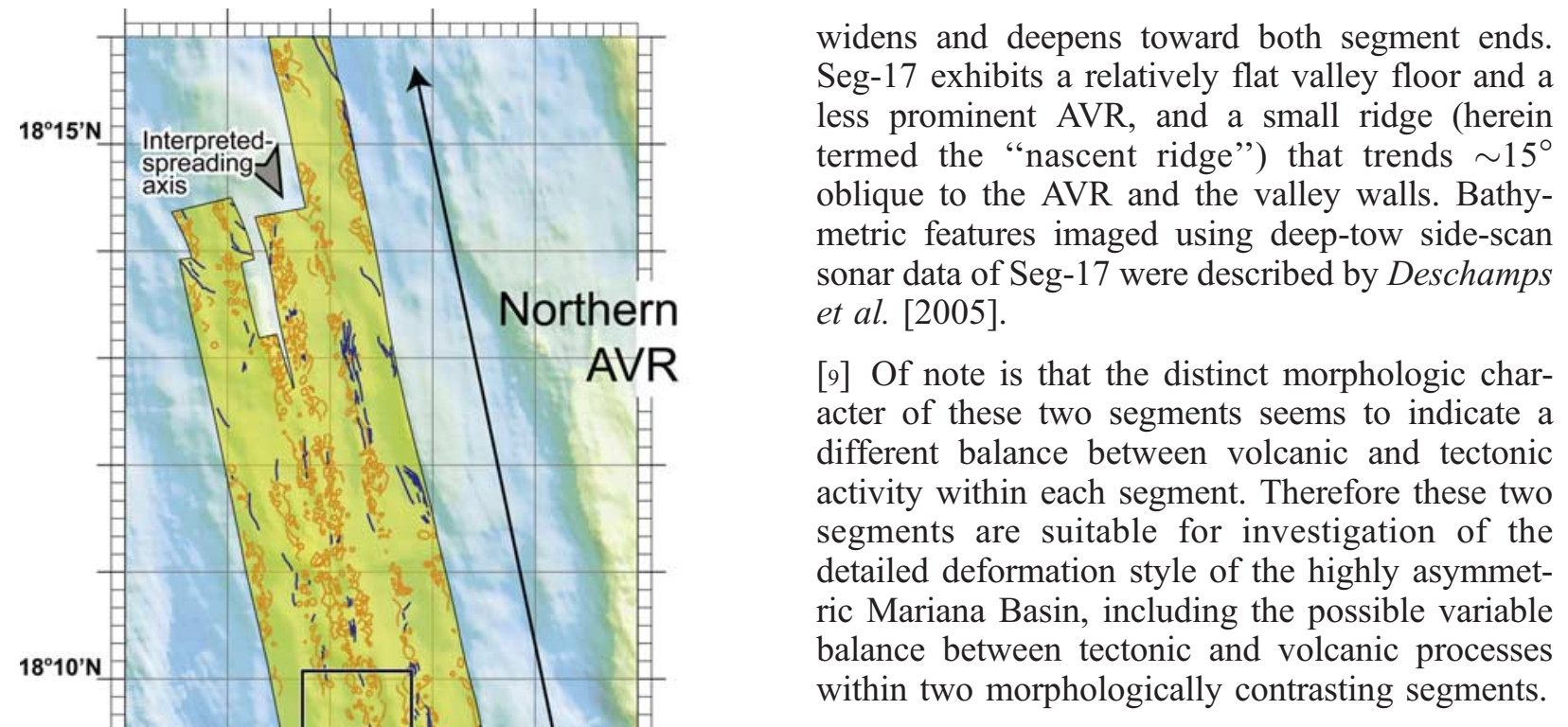

\section{Data Acquisition}

[10] Data for this study were collected with the hull-mounted multibeam and deep-tow side-scan sonar systems aboard R/V Kairei, operated by the Japan Agency for Marine-Earth Science and Technology (JAMSTEC), during the MICROMAR cruise in the central Mariana Basin.

\subsection{Hull-Mounted Multibeam System}

[11] Multibeam bathymetry and backscatter data were simultaneously acquired using a $12 \mathrm{kHz}$ SeaBeam 2112 system. During the topographic surveys, the ship's speed was kept at 5-6 knots [Deschamps et al., 2004, 2005]. Spacing of ship's track and horizontal resolution is $\sim 7 \mathrm{~km}$ and $50 \mathrm{~m}$, respectively.

\subsection{Near-Bottom Side-Scan Sonar Data Acquisition}

[12] The $100 \mathrm{kHz}$ Wadatsumi side-scan sonar vehicle, which has two rows of receivers on each side, was towed $\sim 300 \mathrm{~m}$ above the seafloor. Ship's speed was $\sim 1.7$ knots. The full swath width was $\sim 1 \mathrm{~km}$, and the sampling interval was $1.0 \mathrm{~s}$. The across-track resolution is $\sim 50 \mathrm{~cm}$. The manufacturer of the Wadatsumi specifies a horizontal resolution of $50 \mathrm{~cm}$ (across track) $\times 87.4 \mathrm{~cm}$ (along track).

ment, "Seg-17", is located farther south, between $16^{\circ} 40^{\prime} \mathrm{N}$ and $17^{\circ} 30^{\prime} \mathrm{N}$ (Figure $1 \mathrm{~b}$ ) and is character-

Figure 2b. Geological map of Seg-18. Solid arrows, circle, and narrow arrows have the same meanings as in Figure 2a. Underlain image is bathymetry map. ized by an hourglass-shaped axial valley that

Figure 2a. Wadatsumi side-scan sonar imagery of Seg-18. Location in Figure 1a. The segment center is located near the northern end of this area, and the segment end is located southward. Thick arrows indicate the location of the interpreted-spreading axis of this segment. Boxes are displayed in Figure 6. Note that a circular seamount (black circle) stands up between the northern and the southern AVRs (narrow arrows). 
Geochemistry

)

Geosystems U

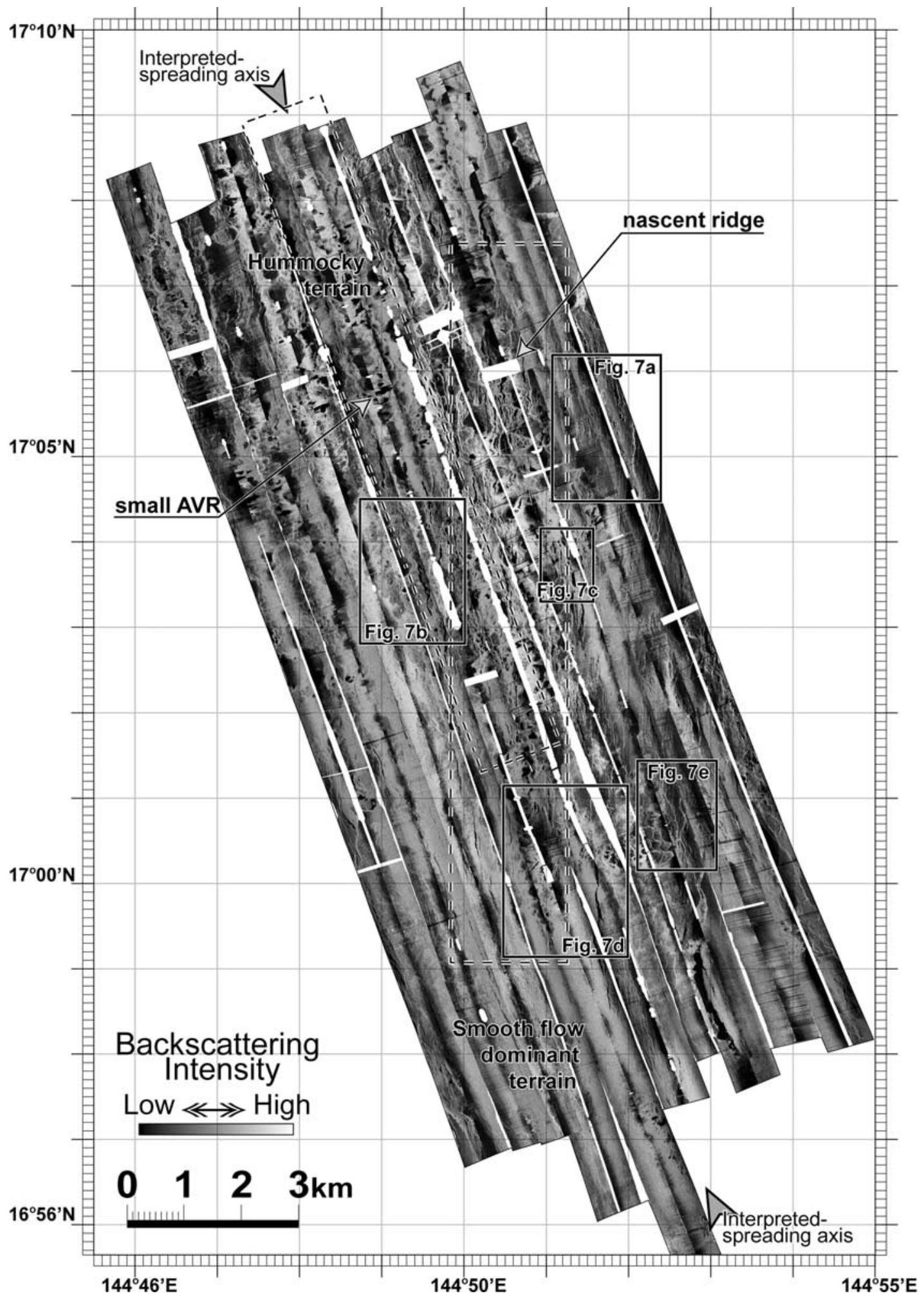

Figure 3a. Wadatsumi side-scan sonar imagery of Seg-17. Location in Figure 1b. The segment center is located at the southern end of this area, and the segment end is located northward. Thick arrows indicate the interpretedspreading axis of the segment. Boxes are displayed in Figure 7. The two dotted boxes indicate the locations of the small AVR and of the nascent ridge. Note that the nascent ridge is constructed by numerous hummocks and is cut by linear tectonic structures. At the segment center (lower part of the image), smooth surface lava flows dominate. 


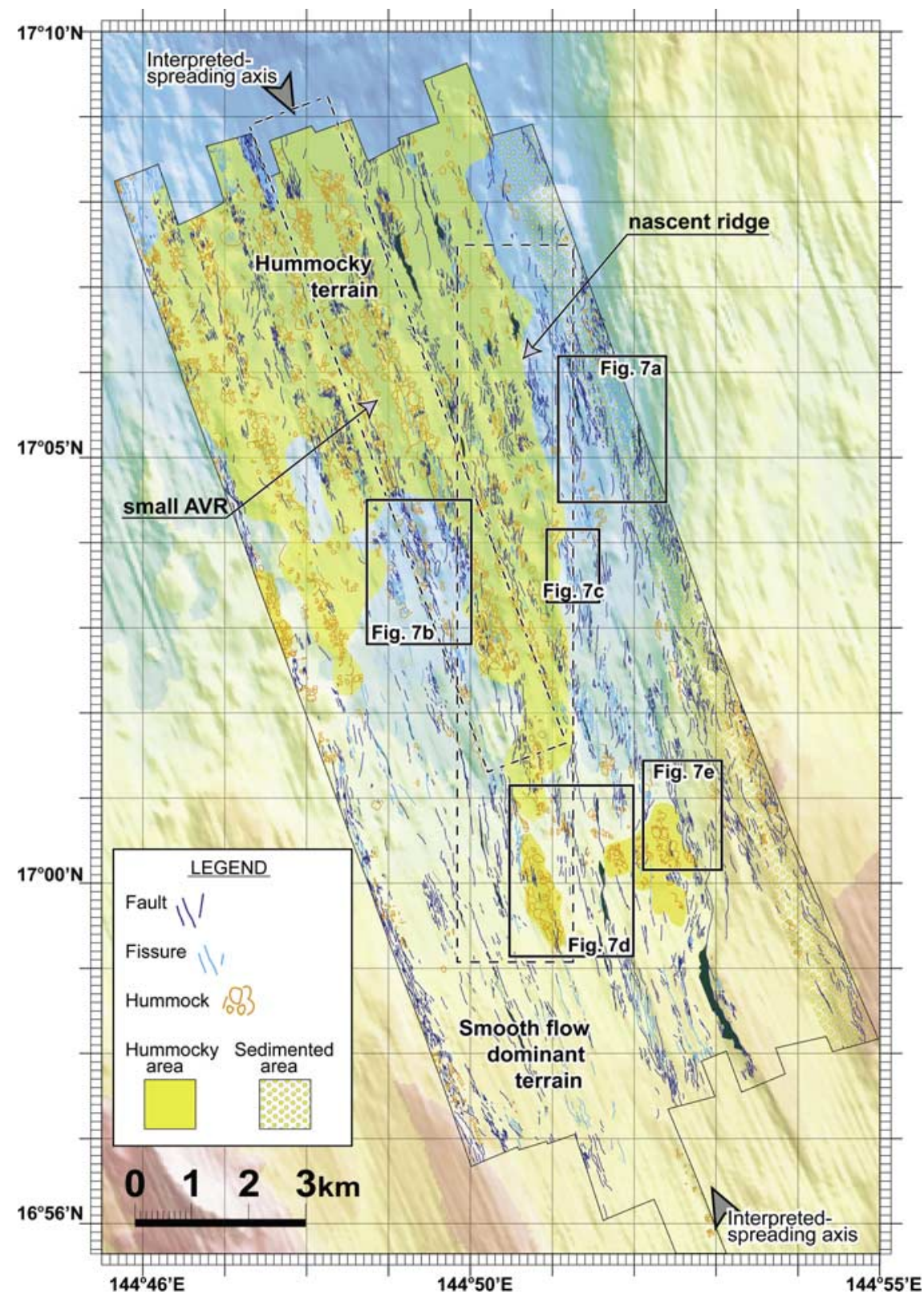

Figure 3b. Geological interpreted map of Seg-17. Solid arrows, boxes, and dotted box have the same meanings as in Figure 3a. Underlain image is bathymetry map. Areas marked by green are selected outstanding fault scarps or acoustic shadows.

[13] Data were collected at Seg-18 along four parallel, 22-25 km-long lines covering the segment center to its southern segment end. The resulting image mosaic, centered along the AVR, is $\sim 4 \mathrm{~km}$ wide and covers $\sim 100 \mathrm{~km}^{2}$ (Figures 2a and $2 \mathrm{~b}$ ). At Seg-17, data were acquired along ten parallel 20-22 km-long lines from the segment center toward its northern segment end, resulting in a $\sim 10 \mathrm{~km}$ wide mosaic encompassing $200 \mathrm{~km}^{2}$ (Figures 3a-3d).
[14] Phase bathymetry data were calculated through differences in arrival angles between the two rows of hydrophone receivers. The resolution of the phase bathymetry data is specified to be $0.3 \%$ of the towfish altitude.

\subsection{Wadatsumi Data Processing and Corrections}

[15] Postprocessing of the side-scan sonar and phase bathymetry data included noise reduction, 


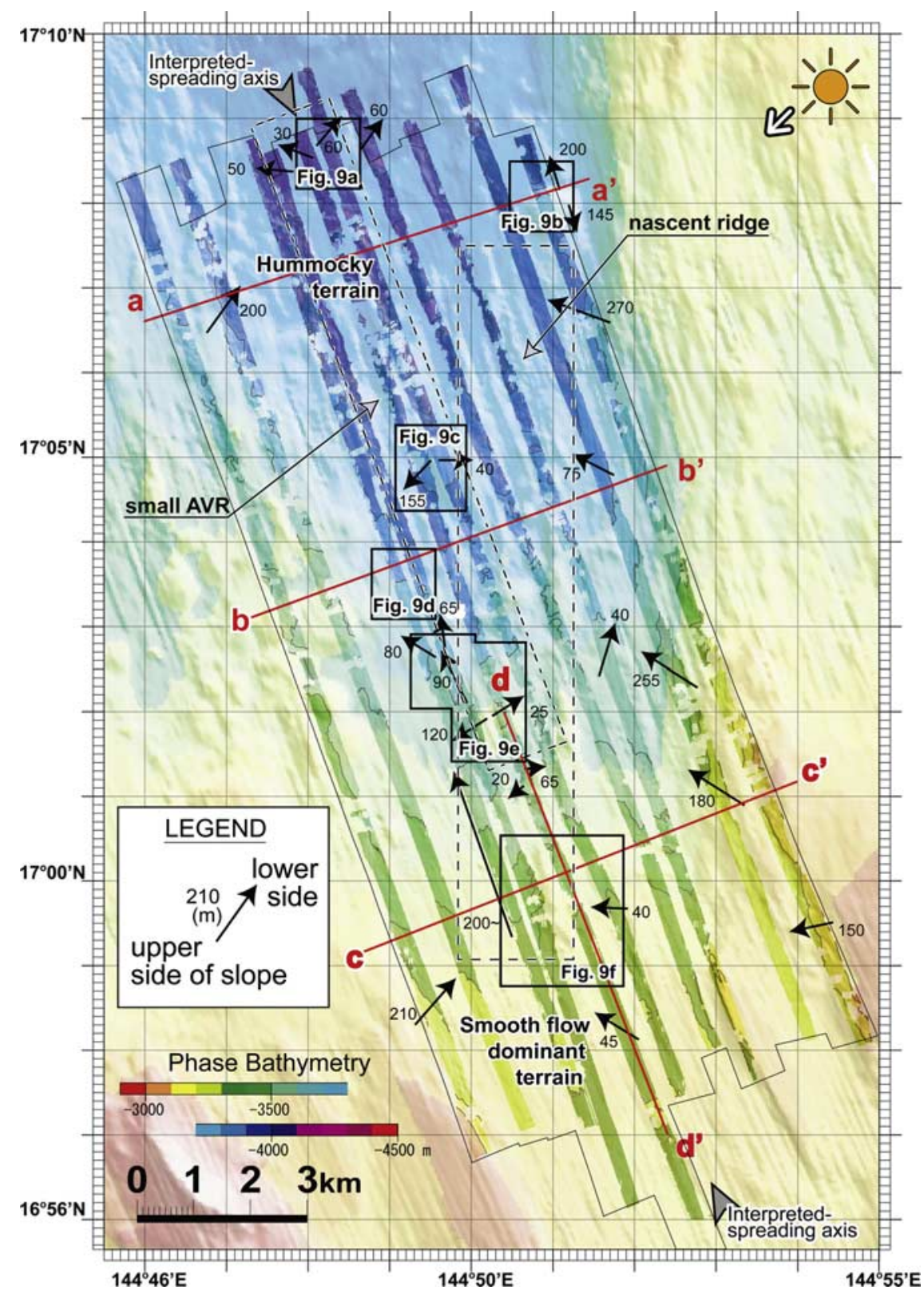

Figure 3c. Phase bathymetry image of Seg-17. Contour interval is $100 \mathrm{~m}$. Solid arrows and dotted box have same meaning as Figure 3a. Boxes are displayed in Figure 9. Red lines indicate the locations of cross sections (Figure 3d). Underlain image is bathymetry map.

radiometric correction, altitude correction, gainlevel correction, and bottom-tracking error correction. Operation of the sonar system above the rough bathymetry that characterizes the surveyed axial valleys was technically difficult, resulting in frequent noise and bottom tracking errors. Thus the effective resolution is substantially lower than the manufacturer's specifications, especially on the port side of the towfish over Seg-18. Linear and planar features longer than $\sim 20 \mathrm{~m}$ were identified for geological interpretation.

[16] A layback-correction was applied to calculate vehicle navigation using its heading, the ship's position, and the relative distance between them (see Appendix A for complete details), because navigational accuracy of a Super Short Baseline System was insufficient during the survey. The navigation data were subsequently averaged using a 30-minute-long moving window with 1-minute 

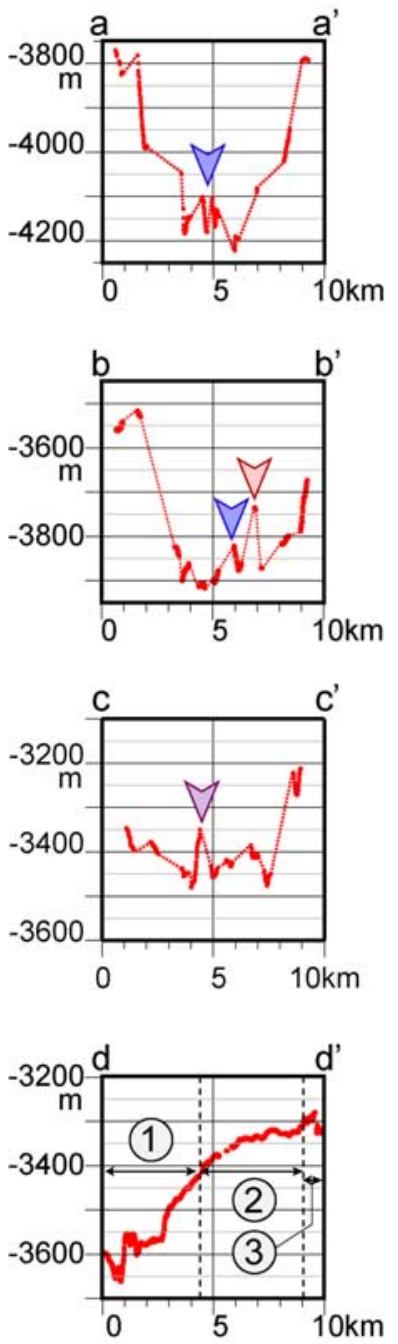

Figure 3d. Cross sections of phase bathymetry. Locations of lines in Figure 3c. The dotted lines indicate areas where there are no data. Blue arrows (lines $a-a^{\prime}$ and $b-b^{\prime}$ ) indicate the small AVR. Pink arrow (line $b-b^{\prime}$ ) indicates the nascent ridge, and the purple arrow (line $c-c^{\prime}$ ) indicates topographic high that locates at the intersection of the small AVR and the nascent ridge. For line d-d': 1, nascent hummocky ridge area; 2 , smooth flow area; 3 , area of hummocks locates on the segment midpoint.

steps. For further positioning correction, the sidescan sonar image mosaic was superimposed on the multibeam bathymetry map. Minor adjustments were applied to the sonar image on the basis of visual recognition of several large features that are well defined in both images. Good consistency between the multibeam and side-scan data indicates that proper corrections were applied. Eventually, the corrected positions were carried over to the phase bathymetry data. Measurements of lengths and azimuths of linear features, and sizes and azimuths of planar features, on the side-scan sonar imagery were carried out using "Scion Image" (Scion Corporation) software.

\section{Observations}

\subsection{Geological Features Revealed by Near- Bottom Side-Scan Sonar Data}

[17] The side-scan sonar data (Figures 2a and 3a) were interpreted using methodology and parameters adopted from previous studies of other slowspreading mid-ocean ridges [e.g., Smith and Cann, 1992; Smith et al., 1995; Head et al., 1996; Sauter et al., 2002]. The light colors indicate high backscattering intensity that likely indicates relatively fresh terrain and scarps facing the sonar vehicle. The dark colors indicate old, sedimented terrain and shadows. Three main types of geological features are identified: linear features (faults and fissures), lava flows (hummocky and smooth), and sedimented terrain (Figures $2 \mathrm{~b}$ and $3 \mathrm{~b}$ ). The height of several structures can be measured using phase bathymetry data.

\subsection{Observations of Seg-18}

\subsubsection{General Structure of Seg-18}

[18] The axial valley walls and AVR of Seg-18 trend $\sim 160^{\circ} \mathrm{E}$. The AVR is separated into two parts, referred to as the northern and southern AVRs (Figure 1a). The northern AVR is relatively wide and flat, while the southern AVR exhibits a sharper and more prominent morphology. A $\sim 100$ m-high conical seamount is located between the northern and southern AVRs. The deep-tow side-scan sonar data cover most of the northern AVR and a portion of the southern AVR, including the location of the "Alice Spring Field" $\left(18^{\circ} 12.9^{\prime} \mathrm{N}\right.$, $144^{\circ} 42.5^{\prime} \mathrm{E},-3600 \mathrm{~m}$; Figure 1a), which was discovered during Alvin dives in 1988 [Hawkins et al., 1990]. This site is located on a west-facing scarp of the northern AVR. Hawkins et al. [1990] reported angular rocks and live animals in the vicinity of the hydrothermal vents. However, these are not identifiable in our images.

\subsubsection{Side-Scan Sonar Imagery of Seg-18}

\subsubsection{In Situ Observations of Side-Scan Sonar Imagery}

[19] Ground-reference of the side-scan sonar imagery was possible through comparison of our data with in situ submersible observations of two 


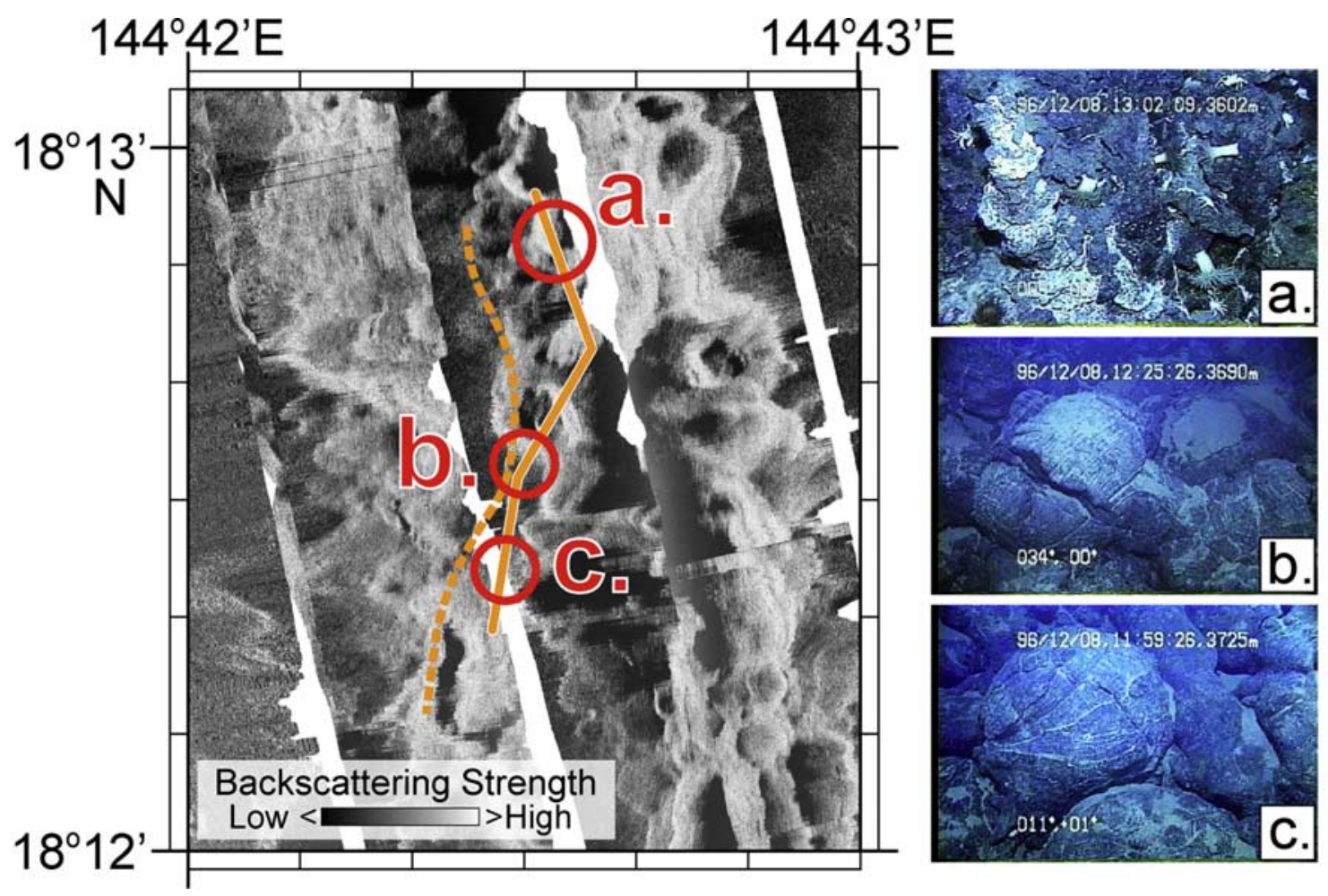

Figure 4. Close-up side-scan sonar image of Seg-18 (left) and photos taken by submersible Shinkai 6500 (right). Orange dotted line indicates track line of the Shinkai 6500 reported by Gamo et al. [1994]. Orange solid line is an estimated track line based on detailed comparison of microbathymetry between video records and sonar image. Photos taken at a, b, and c sites are shown on the right side. Positions of the photos on side-scan sonar image are determined on the basis of the estimated track line and recorded times.

Shinkai 6500 dives around the Alice Spring Field [Gamo et al., 1994; Fujikura et al., 1997]. The seafloor observations indicate that most of the area consists of accumulated pillow basalts commonly covered by a thin sediment veneer, while hydrothermal vents and related angular rocks are limited to a relatively small area in which microbial mats thrive (Figure 4). The boundary between these different seafloor morphologies, i.e., the bases of chimneys and related rocks and pillow basalts, is recognizable in the video records, but not visible in our data.

[20] The submersible track, obtained using an acoustic-ranging system that determines relative position to mother ship navigated by GPS, was plotted on our side-scan sonar image mosaic (Figure 4, orange dotted line). However, the submersible data did not agree with our microbathymetry information based on the pattern of backscattering intensity. The orange solid line (Figure 4) is an estimated track line based on detailed comparison of microbathymetry between video records and sonar imagery. An approximate
$100 \mathrm{~m}$ northeastward shift of the submersible track resulted in perfect agreement. Ground-reference indicates that the pillow basalts are expressed as hummocky terrain in our side-scan sonar imagery (Figure 4). The angular rocks associated with hydrothermal vents and the thin layer of sediment and microbial mats were not resolved.

\subsubsection{Lava Flows}

[21] The side-scan sonar imagery of Seg-18 reveals a ubiquitous hummocky texture that consists of conglomerations of numerous, circular or elongate mounds, with diameters ranging from a few tens to a few hundreds of meters (Figures $2 a$ and $2 b$ ). Hummocks exhibit rounded summits with no craters and are developed over the flanks of both parts of the AVR. A total of 1443 hummocks were counted over the $100-\mathrm{km}^{2}$ area. This number represents a minimum estimate because stacked hummocks are expressed as one large cobbly hummock and boundaries between individual hummocks are difficult to distinguish in places. No smooth terrain is observed. 


\section{Seg-18}
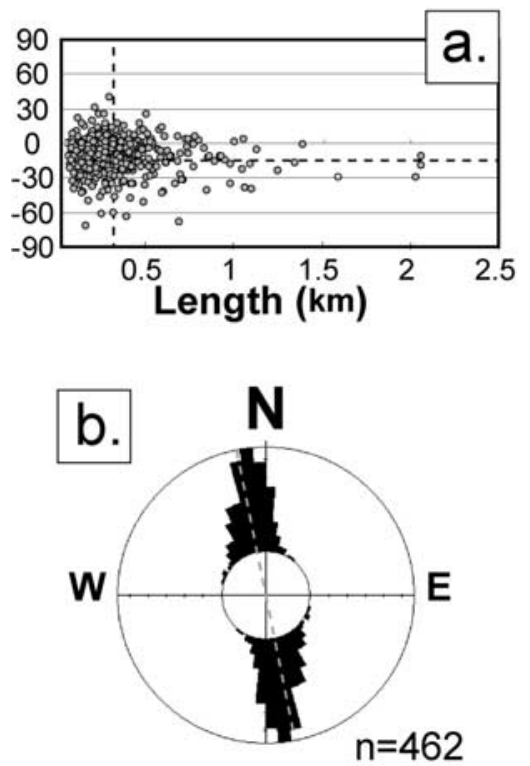

Seg-17
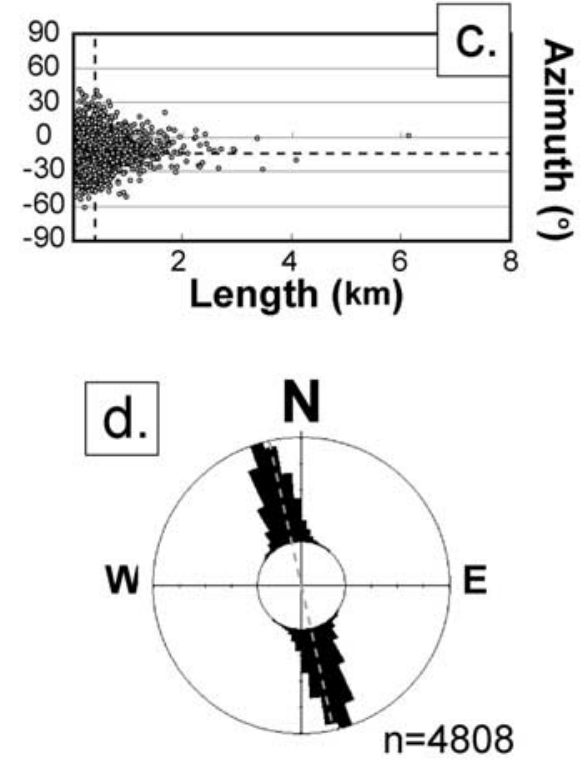

Figure 5. (a) Plot of fissures and fault azimuth versus length of Seg-18. Dotted lines indicate average of length and azimuth. (b) Rose diagram indicating distribution of azimuth of Seg-18. Dotted line indicates average azimuth. (c) Plot of azimuth versus length of Seg-17. (d) Rose diagram indicating azimuth distribution at Seg-17.

\subsubsection{Linear Features}

[22] Within the hummocky terrain, linear features are sparsely expressed. They are typically concentrated in particular regions, such as the flat summit of the northern AVR. A total 462 linear features were recognized (Figures $2 \mathrm{a}$ and $2 \mathrm{~b}$ ). Linear features are also observed on the steeper southern AVR. The small linear features exhibit a more variable trend than the longer linear features. We cannot distinguish faults or fissures from the sidescan sonar imagery alone in Seg-18; narrow widths of the features and lower image resolution prevent us from doing so. Average lineament length, azimuth, and the standard deviation of the azimuths are $320 \mathrm{~m}, 170^{\circ} \mathrm{E}$, and $15^{\circ}$, respectively (Figure 5). The average azimuth $\left(170^{\circ} \mathrm{E}\right)$, which is characterized by a large standard deviation $\left(15^{\circ}\right)$, is slightly oblique to the trend of axial valley wall $\left(\sim 160^{\circ} \mathrm{E}\right)$ (Figure 5). The linear features exhibit increased variability relative to linear features that developed under an ideal, single extensional stress field. On the basis of clay models of Bellahsen et al. [2003], our own measurements (number $=455$ ) result in a standard deviation of $7.5^{\circ}$ under an ideal, single stress field. Due to the sparse distribution of linear features, direct crosscutting relationships were not observed.

\subsubsection{Phase Bathymetry Data}

[23] The phase bathymetry data of Seg-18 generally exhibits a cobbly surface throughout the entire area, which is consistent with sonar observations showing a dominant hummocky terrain. Rough features, interpreted as stacked hummocky terrain, independent conical seamounts perched on the cobbly terrain, or gently sloping terrain are also recognizable in the phase bathymetry image, although individual hummocks and linear features are not easily recognized. Ridge branches and valley inclinations that are not expressed in the side-scan sonar image are apparent in the phase bathymetry image (Figure 6).

\subsection{Observations of Seg-17}

[24] Limited surface bathymetry and sonar images with interpretations of Seg-17 were presented in a previous paper [Deschamps et al., 2005]. Here, we present a detailed interpretation of the entire sonar image accompanied by phase bathymetry data.

\subsubsection{General Structure of Seg-17}

[25] The hourglass shaped axial valley floor of Seg-17 exhibits a smooth surface at the segment center and rough morphology toward its northern end [Deschamps et al., 2005]. The AVR has 

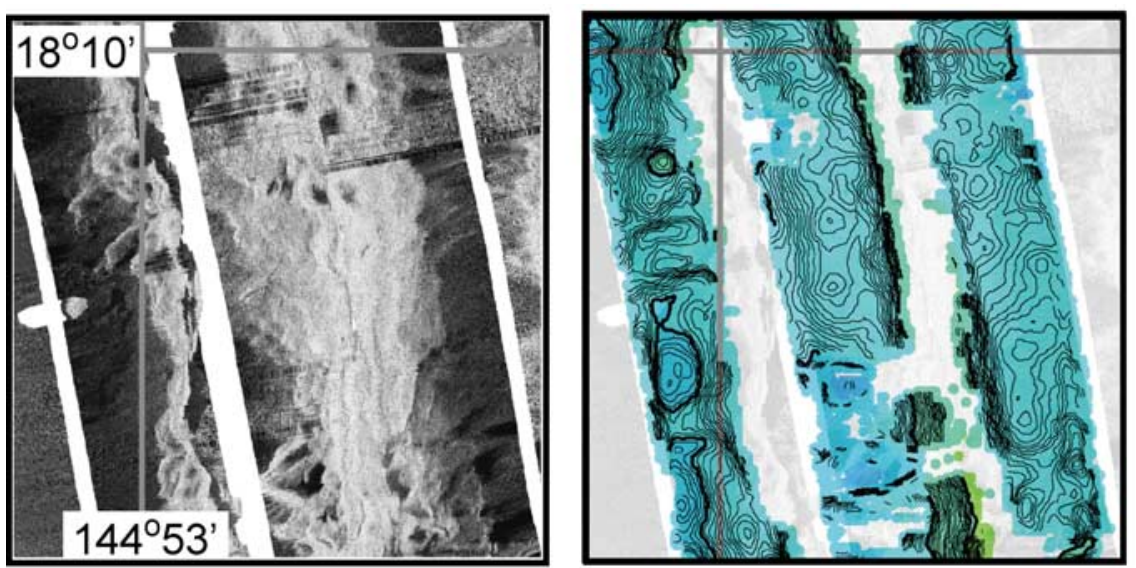

a.
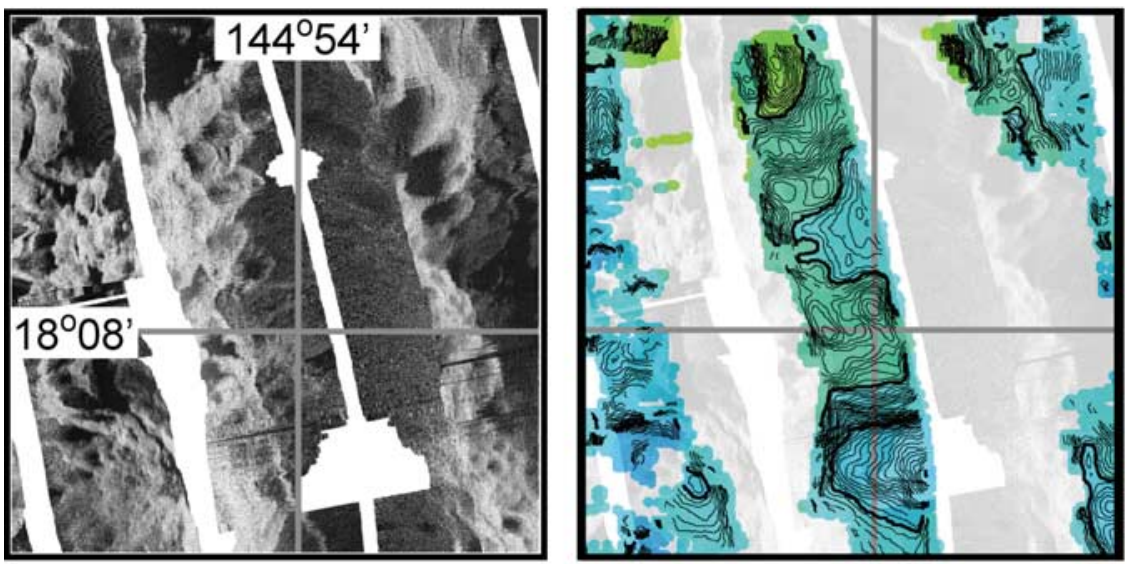

b.

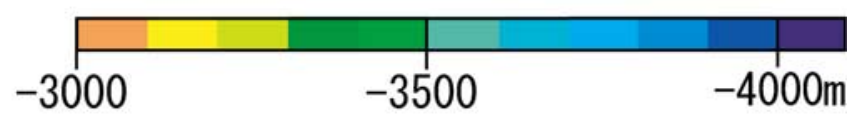

Figure 6. (left) Close-up sonar images and (right) their phase bathymetry of Seg-18. Positions of each image coincide with numbered boxes in Figure 2a. Contour interval is $5 \mathrm{~m}$.

limited relief ( $\sim 100 \mathrm{~m}$ maximum), and the axial valley walls are not as well expressed as those of Seg-18 ( $\sim 800 \mathrm{~m}$ maximum relief versus $\sim 100 \mathrm{~m})$. The eastern axial valley wall is steeper and more linear than the western wall. The 10 side-scan sonar survey lines provide partial coverage of the eastern valley wall but do not reach the western axial valley wall.

\subsubsection{Side-Scan Sonar Imagery of Seg-17}

\subsubsection{Lava Flows}

[26] Lava flows exhibit various morphologies and surface textures, varying from smooth to hum- mocky (Figures 3a and 3b). Such a change of surface morphology is consistent with the topographic change observed on multibeam surface bathymetry data [Deschamps et al., 2005].

[27] Smooth flow dominates the segment center, although several hummocks are localized at the segment midpoint. Cobbly hummocky terrain is well developed on the northern margin toward the deeper segment end. Interpretation of the side-scan image mosaic (Figure 3b) indicates that smooth terrain, which comprises almost $100 \%$ of the area at the segment center, is progressively replaced by hummocky terrain proceeding northward, and comprises $<20 \%$ of the seafloor $20 \mathrm{~km}$ the north 
of segment midpoint. A V-shaped boundary between the hummocky and smooth terrains points southward (Figure 3b, outline of yellowish colored area) and is relatively linear to the east, but less regular to the west. This sharp eastern boundary nearly corresponds to the foot of the steep eastern axial valley wall.

[28] A nascent ridge that trends $\sim 175^{\circ} \mathrm{E}$ is another prominent feature of Seg-17. The nascent ridge consists of accumulated hummocks and trends $\sim 15^{\circ}$ oblique to the large-scale trend of the valley. The ridge appears superimposed upon smooth lava flows.

[29] A total of 1361 hummocks were counted, which is likely a minimum estimate. Hummock size is consistent across separate regions, including the western flank of segment margin, nascent ridge, segment midpoint, and the northern part of the interpreted segment axis.

\subsubsection{Linear Features}

[30] The linear structures at Seg-17, interpreted as faults and fissures, are well developed and clearly expressed in the side-scan sonar image mosaic. We identified 4808 such features in the approximately $200-\mathrm{km}^{2}$ Seg-17 study area Many of them display cross-cutting relationships. The average length, average orientation, and azimuth standard deviation are $200 \mathrm{~m}, 166^{\circ} \mathrm{E}$, and $11^{\circ}$, respectively (Figure 5). This standard deviation is larger than what would be expected under a single, ideal stress field $\left(7.5^{\circ}\right.$, based on result from Bellahsen et al. [2003]). The population of linear features observed at Seg-17 is an order of magnitude larger, yet exhibits a lower standard deviation, as well as different overall characteristics, than that of Seg$18\left(\mathrm{n}=462\right.$; standard deviation $\left.=15^{\circ}\right)$, which exhibits a uniform character throughout.

[31] The characteristics of the linear features within the western, central, and eastern areas of Seg-17 differ (Figures 3a and 3b). Along the western flank of the segment margin, within the relatively flat axial valley floor adjacent to, but not including, the steeper western axial valley wall, faults and fissures are relatively sparse and trend $\sim 160^{\circ} \mathrm{E}$. Within the central portion of the image mosaic, which includes the small AVR along the interpreted spreading axis, the northern end of the nascent ridge, as well as the segment midpoint, linear features are more common and exhibit two distinct trends, either parallel to the segment $\left(\sim 160^{\circ} \mathrm{E}\right)$, or parallel to the nascent ridge at $\left(\sim 175^{\circ} \mathrm{E}\right)$. Features trending in both directions are observed within the hummocky and smooth terrain. They commonly cut lava flows. They are also partially overprinted by fresher flows in places.

[32] Along the eastern flank of the segment, linear features are much more complex. In addition to faults and fissures trending both $\sim 160^{\circ} \mathrm{E}$ and $\sim 175^{\circ} \mathrm{E}$, wide, irregular fissures, $\leq 500 \mathrm{~m}$ long and $\sim 100 \mathrm{~m}$ wide, are present in the steep eastern axial valley wall (Figure 7a). These wide fissures trend nearly north-south, indicating a potential relationship with the nascent ridge that also trends nearly N-S $\left(\sim 175^{\circ} \mathrm{E}\right)$. A side-scan sonar image shows similar wide and irregularly shaped downward-concave features on ridge crests along the East Pacific Rise [e.g., Fornari et al., 1998; White et al., 2000, 2002]. White et al. [2000] interpret the similar "collapse" feature are drained lava lakes which are ubiquitous on Mid Ocean Ridge (MOR) crests [e.g., Engels et al., 2003]. Another possibility is large fissures produced by dyke intrusion [Head et al., 1996; Mastin and Pollard, 1988]. If so, they require that fresh lava flows occur not only on the axial valley floor, but also near the axial valley wall.

[33] The population of linear features, when considered as a whole, is normally distributed with a mean azimuth of $166^{\circ} \mathrm{E}$ (Figure 5). However, dividing the study area into $0.5-\mathrm{min} \times 0.5-\mathrm{min}$ boxes reveals two distinct populations, referred to respectively as I-Type and X-Type, that exhibit a modal azimuth of $160^{\circ} \mathrm{E}$ (i.e., parallel to the rough direction of the axial valley), and a bimodal azimuth of $160^{\circ} \mathrm{E}$ and $175^{\circ} \mathrm{E}$ (nascent ridge-parallel) (Figure 8). This quantitatively confirms that obliquely trending linear features are confined to a limited area located between the interpreted axis and the eastern wall of the axial valley, encompassing the nascent ridge, as observed by Deschamps et al. [2005]. This region exhibits a higher fracture density than the western part of the valley, which indicates that it has likely experienced a higher degree of deformation.

\subsubsection{Crosscutting Relationships of Tectonic Structures}

[34] Although age relationships cannot be determined definitively on the basis of side-scan sonar imagery alone, our data suggest several relationships. The tectonic deformation that is responsible for the development of both parallel and oblique linear features likely occurred simultaneously with volcanic activity. Both $160^{\circ} \mathrm{E}$ and $175^{\circ} \mathrm{E}$ trending linear features cut, but are also partly overprinted, 

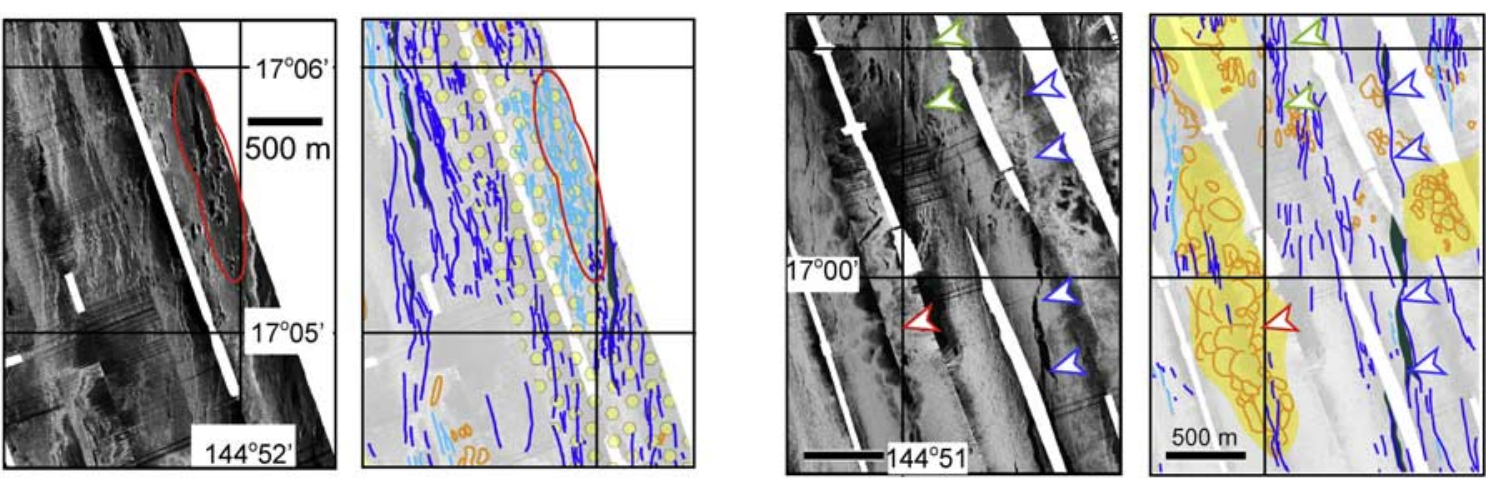

a.

d.
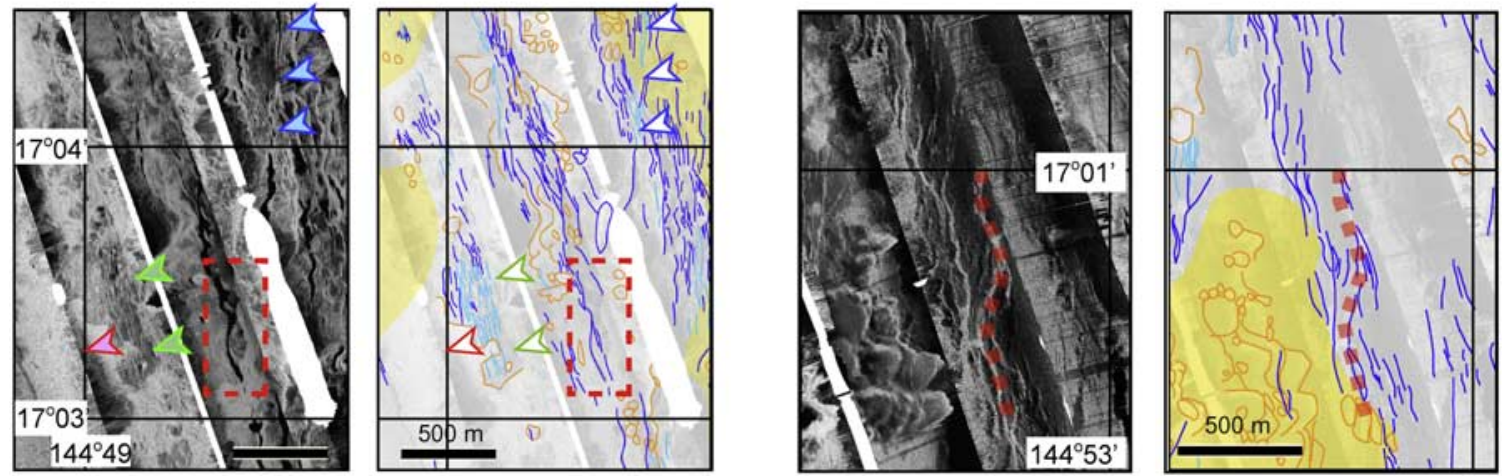

b.

e.
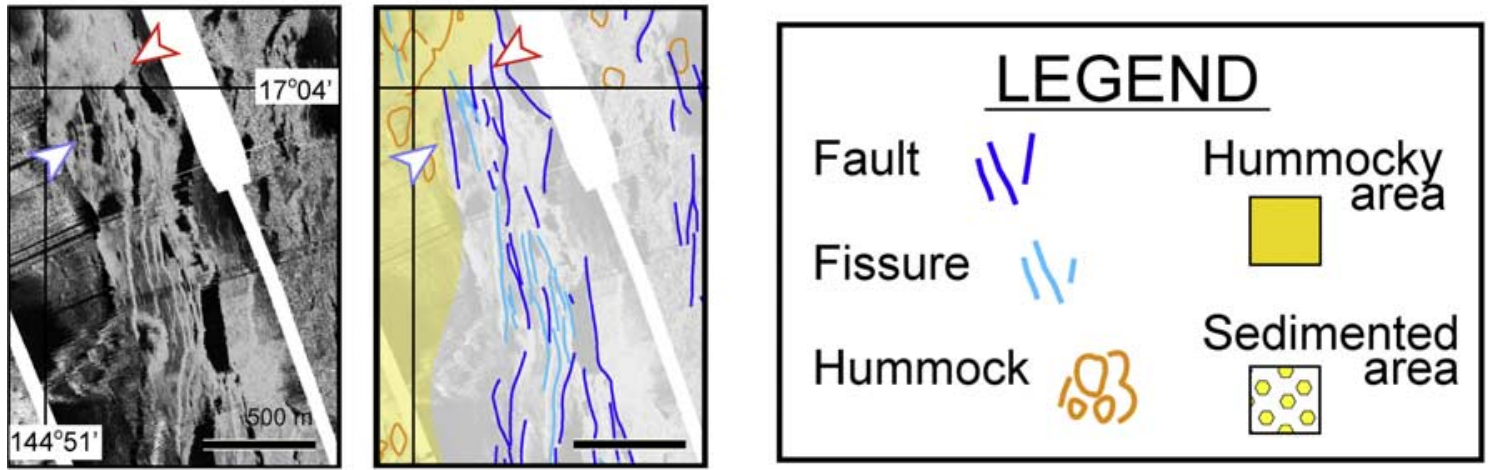

C.

Figure 7. (left) Close-up sonar images and (right) their geological interpretations of Seg-17 selected areas. Positions of each image are shown in Figures 3a and 3b. (a) Red circle indicates wide fissures developed on eastern axial valley wall. (b) Example of crosscutting relationship between faults, fissures, and lava flows. Blue thick arrows indicate $175^{\circ} \mathrm{E}$ trending fissures that developed above $160^{\circ} \mathrm{E}$ trending faults. Green arrows indicate $160^{\circ} \mathrm{E}$ trending faults and fissures covered by newer lava flows. Red arrow indicates the most recent lava flow in this area. The area covers the boundary of the small AVR and of the nascent ridge. Note that the fault changes its direction at the limit between the two structures (red dotted box). (c) Another example of crosscutting relationship between geological features. Blue thick arrow indicates $175^{\circ} \mathrm{E}$ trending fault covered by newer lava flow indicated by red arrow. (d) Red arrow indicates hummocky terrain developed on smooth surface lava flow near the segment center. The site of the hummocky terrain shows good correlation with a southern end of the nascent ridge. Blue and green arrows indicate different $175^{\circ} \mathrm{E}$ trending faults. Note that $175^{\circ} \mathrm{E}$ trending faults and fissures widely developed on both smooth surface and hummocky lava flows. (e) Example of linked faults (red dotted line). 


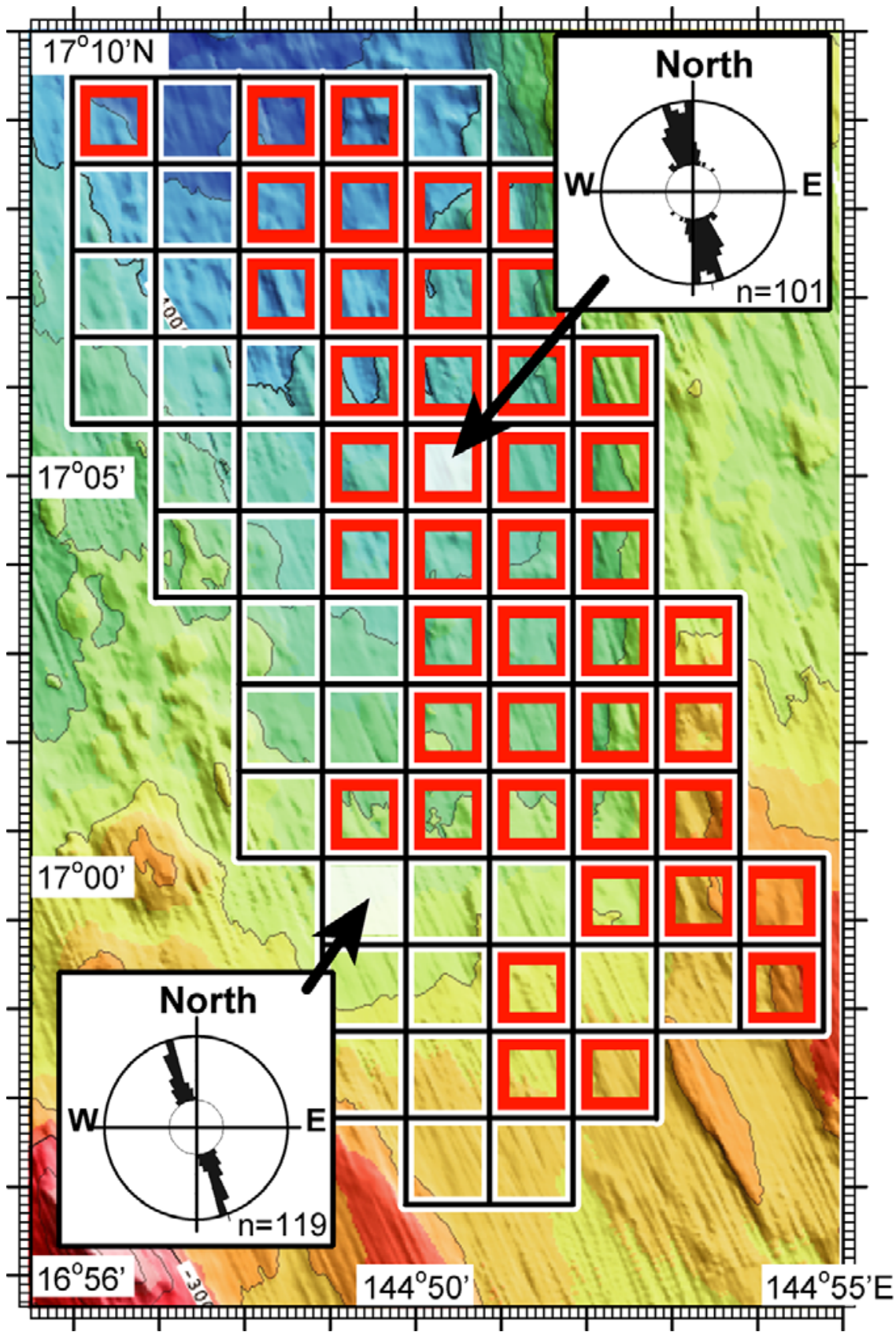

Figure 8. Examples of rose diagram tectonic feature azimuth. The size of each box is 0.5 -min by 0.5 -min, and linear features that touch the boundary of each box are counted for measurement. Two types of diagrams are output: I-type (bottom, left; $160^{\circ} \mathrm{E}$ trending structures are dominant) and X-type (top, right; both $\mathrm{N} 160^{\circ} \mathrm{E}$ and $\mathrm{N} 175^{\circ} \mathrm{E}$ trending structures are dominant). Red boxes indicate where the X-type diagrams were obtained. Note that diagrams indicating X-type are commonly dominant in eastern margin of Seg-17.

by lava flows (Figures $7 \mathrm{~b}$ and $7 \mathrm{c}$ ). The nascent ridge appears to be younger than the small AVR because faults developed on the AVR seem to change direction from $160^{\circ} \mathrm{E}$ to $\sim \mathrm{N}-\mathrm{S}$ at the boundary between the two structures (Figure 7b). The $\mathrm{N} 175^{\circ} \mathrm{E}$ trending features are indeed likely the younger of the two types of lineaments, as they tend to cut the newer lava flows that in turn cover the $160^{\circ} \mathrm{E}$ trending features (e.g., Figures $7 \mathrm{~b}$ and 7d). Features of each trend link together in places (Figure 7e) suggesting no major age differences.

\subsubsection{Phase Bathymetry Data}

[35] Although the high level of noise prevented continuous coverage, especially on the port side of the sonar vehicle, the phase bathymetry nonethe- 
less shows good continuity between adjacent lines. The seafloor is relatively flat over the segment center with a short-wavelength undulation developing toward its northern end. This variation corresponds to changes in volcanic flow morphology, i.e., a northward increasing proportion of hummocky terrain versus smooth terrain. The small AVR and nascent ridge are visible in cross sections of phase bathymetry data (Figure $3 \mathrm{~d}$ ).

\subsubsection{Lava Flows in Phase Bathymetry Data}

[36] Hummocky terrain: Phase bathymetry data show four circular, flat-topped topographic highs, also apparent in the surface multibeam bathymetric map. They exhibit heights between 80 and $280 \mathrm{~m}$ and diameters of $\sim 2 \mathrm{~km}$ (Figures $9 \mathrm{a}-9 \mathrm{c}$ and $9 \mathrm{e}$ ). In the phase bathymetry data, the edges of these features are smooth, standing out against cobbly features of the hummocky terrain, indicating that these features developed subsequent to the creation of the hummocky terrain.

[37] Hummocks are commonly densely distributed and accumulated. The $175^{\circ} \mathrm{E}$ trending nascent ridge near the segment center is clearly expressed as a linear accumulation of hummocks (Figure 9f). This linear hummocky terrain is prominent enough to appear in the surface multibeam bathymetry data, reaching $\sim 150 \mathrm{~m}$ above the surrounding seafloor. This ridge is thus higher than the small AVR (Figure 3d, b-b').

[38] Smooth terrain: To the west of the segment midpoint, phase bathymetry reveals that a gentle, NE-SW dipping slope characterizes the smooth flow area (Figure 3c). This area's change in elevation totals $200-300 \mathrm{~m}$, and is expressed as small steps ranging from 10 to $20 \mathrm{~m}$. These features appear on the side-scan sonar imagery as $160^{\circ} \mathrm{E}$ trending faults with small throws. A lobe-like smooth flow characterizes the gentle slope of the segment center. The smooth flow inclines northward with a steeper inclination at the southern end of the nascent ridge (Figure $3 \mathrm{~d}, \mathrm{~d}-\mathrm{d}^{\prime}$ ). Crosscutting relationships between the smooth flow and the nascent ridge (Figure 9f) are unclear in the phase bathymetry data.

[39] The phase bathymetry data also show relative height differences between crosscutting features. For example, fissures developed within the old smooth flow are partly overprinted by a younger smooth flow (Figure 9d). Phase bathymetry of the same image indicates that the thickness of this recent smooth flow is $15 \mathrm{~m}$ maximum.

\subsubsection{Linear Structures on Phase Bathymetry Data}

[40] The throws of large faults can also be measured on phase bathymetry. Such faults exhibit a zigzag contour pattern (Figure 9f). Arrows in Figure $3 \mathrm{c}$ indicate the quantifiable throws. The lack of continuous coverage precludes measurement and comparison of total throws between differently trending fault groups. The detailed geometry of smaller faults cannot be recognized on the phase bathymetry map, even though they are clearly seen on the side-scan image, indicating that the throws of these small faults are probably less than the $5 \mathrm{~m}$ contour interval of the phase bathymetry map.

\section{Discussion}

\subsection{Large-Scale Differences of Volcanic Activity}

[41] The Wadatsumi side-scan sonar data illuminate various stages of crustal evolution at Seg-17 and Seg-18. At Seg-17, faulting clearly dominates over volcanism, while the opposite relationship is observed at Seg-18. The data show different balances of faulting and volcanism at two distinct segments, with more active volcanism along the AVR of Seg-18 than along Seg-17.

[42] Briais et al. [2000] discussed volcano-tectonic cycles of the Mid-Atlantic Ridge interpreted from side-scan sonar imagery, and suggested that smooth lava flows form during phases of high magmatic flux. In our survey area, a combination of smooth lava flows and hummocky terrain comprises Seg-17 seafloor, whereas hummocky terrain characterizes most of Seg-18 seafloor. This suggests that Seg-17 experienced volcanism with higher flux rates than Seg-18. At the same time, however, other observations suggest the opposite relationship. Seg-17 is characterized by hourglassshaped bathymetry suggestive of magmatic processes dominating over tectonic processes, although it is currently dominated by intense faulting rather than volcanism. On the other hand, Seg- 18 exhibits morphology (wide and deep linear axial valley) typical of segments with low effusion rates of magma, although it has been subjected to very limited deformation and is covered by mostly unfaulted recent flows. This variation seems to be related to alternating magmatic-tectonic phases reported by many authors [e.g., Kappel and Ryan, 1986; Briais et al., 2000]. However, on the basis of 
seismic observations along the Juan de Fuca intermediate spreading ridge, Carbotte et al. [2006] have suggested that the axial rift topography reflects magma intrusion rather than alternating
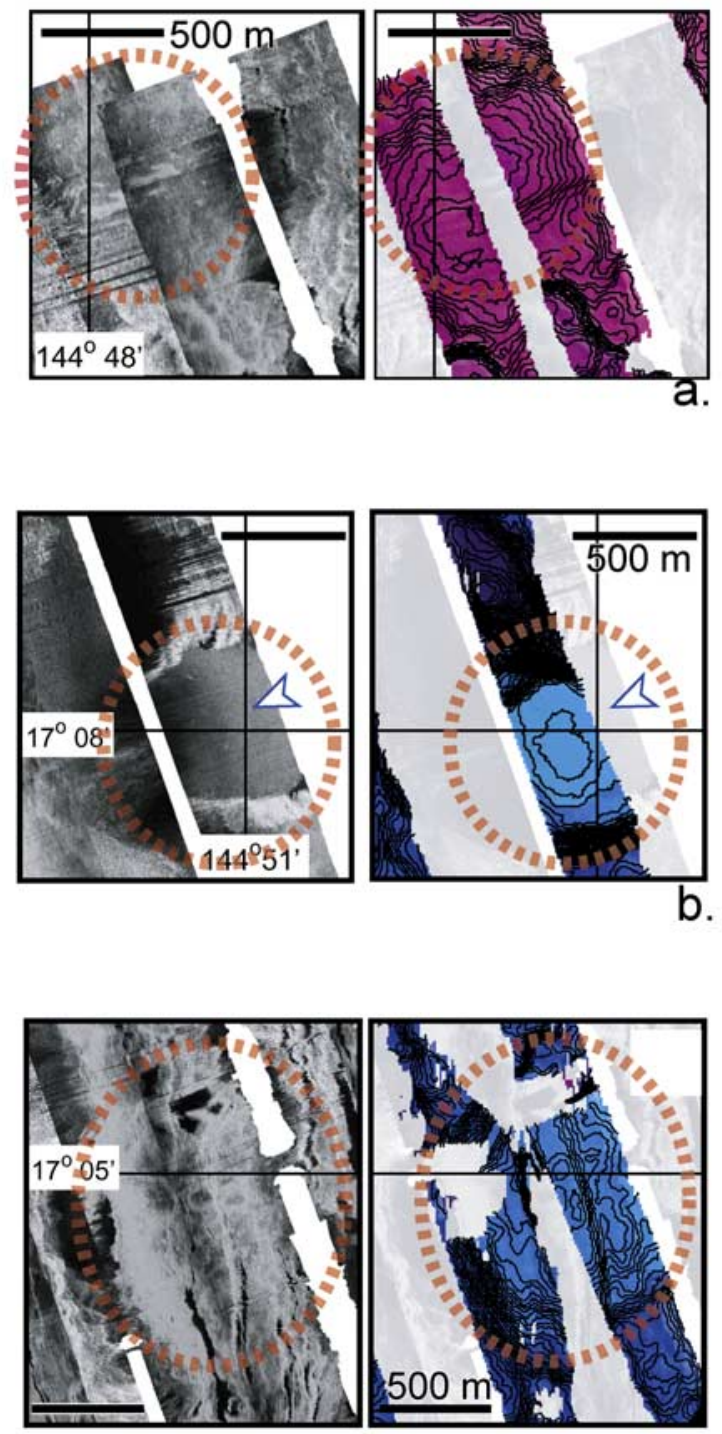

C.
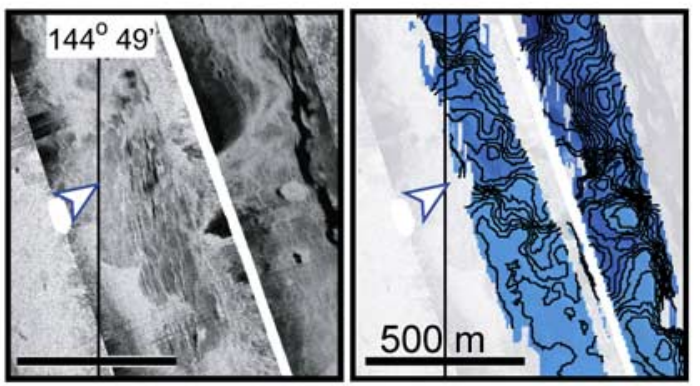

d.

b. phases of magmatism and tectonic extension, as previously proposed [e.g., Stakes et al., 1984; Kappel and Ryan, 1986]. As back-arc spreading centers show processes similar to those of MORs,
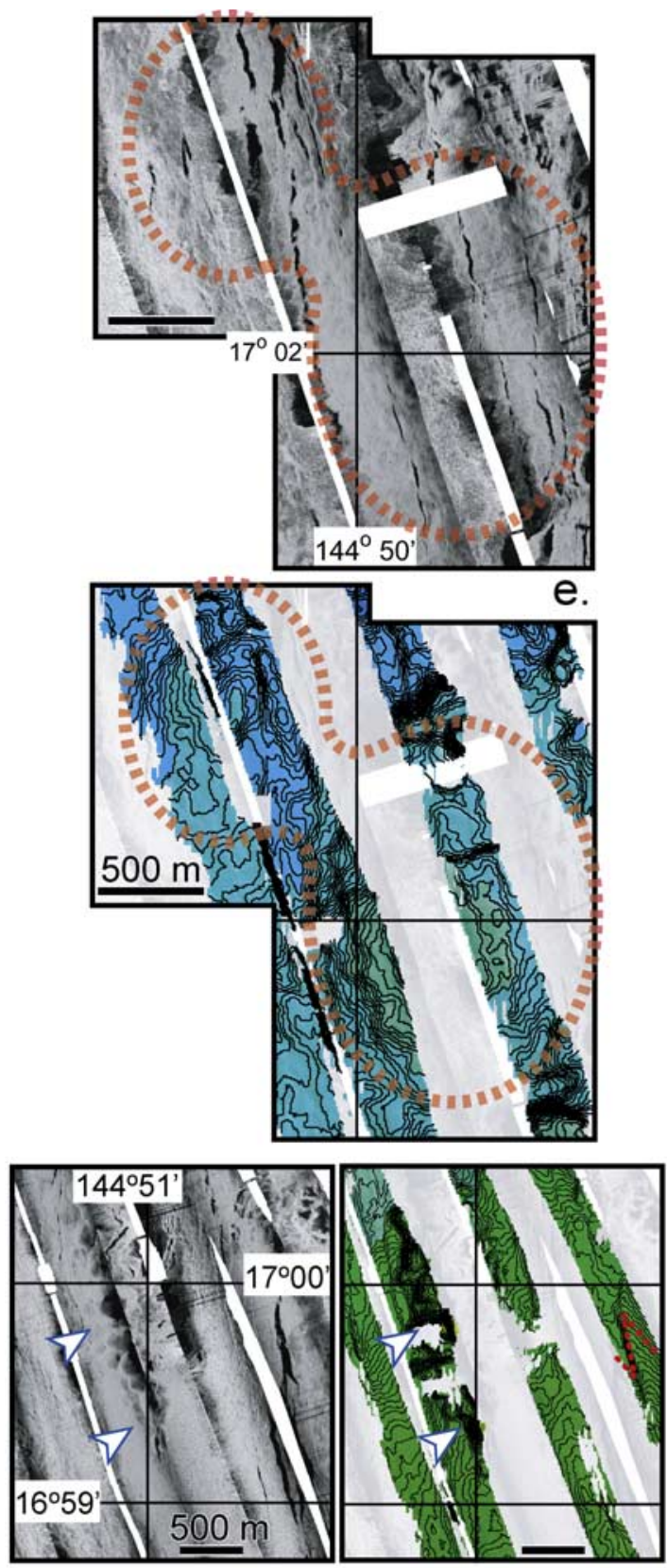

f.

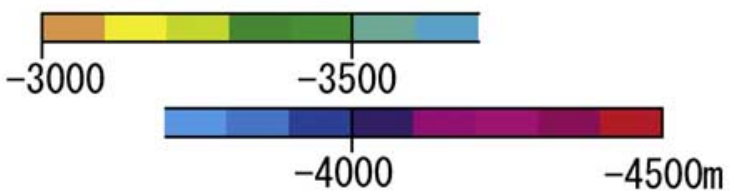

Figure 9 
we cannot rule out the recent hypothesis of Carbotte et al. [2006]. However, components derived from the subducting Pacific Plate may have influence the previous stage of intense volcanism within Seg-17 [Gribble et al., 1996]. Further work is thus required to determine which scenario, a variation of dyke intrusion and seafloor deformation [Carbotte et al., 2006], or unstable input of subduction related-components, has influenced the distinct Seg-17 and Seg-18 morphologies and volcanictectonic patterns.

[43] The degree of volcanic activity also differs within each individual segment. The steeper southern AVR of Seg-18 exhibits fewer linear features than the northern AVR, indicating more intense volcanism at the latter. A smooth lava flow dominates the segment center of Seg-17, while hummocky terrain dominates toward the north. Increasing hummock abundance, meaning increasing accumulated pillow basalts, indicates either a decrease in eruption rate and/or lava-flow temperature, or perhaps an increase in source-magma viscosity and/or in lava flows [e.g., Griffiths and Fink, 1992; Fink and Griffiths, 1998; Gregg and Fornari, 1998].

\subsection{Small-Scale Lava Flow Variation on Seg-17}

[44] The $175^{\circ} \mathrm{E}$ trending nascent ridge in Seg-17 is superimposed upon the smooth flows near the segment center. The age-relationship between the smooth flow and the hummocky nascent ridge likely indicates a physical change in lava flows erupted over the segment center through time. Phase bathymetry data across the ridge indicate that the southernmost portion of the nascent ridge stands $\sim 100 \mathrm{~m}$ above the smooth flow (Figure 3d, c-c' ${ }^{\prime}$ ) and is surrounded by steep scarps (Figure 9f). On the other hand, the phase bathymetry data along the interpreted-axis also shows that the smooth flow gently inclines toward the nascent ridge, with no gap at the intersection (Figure $3 \mathrm{~d}, \mathrm{~d}-\mathrm{d}^{\prime}$ ).
[45] Possible explanations for the positional relationship between the smooth flow and the southern end of the nascent ridge include the following: (1) the smooth lava flow and the nascent ridge were constructed during the same volcanic episode, as reproduced in several laboratory experiments [e.g., Griffiths and Fink, 1992], and thus exhibit the same age; (2) the hummocky ridge is more recent, built upon an existing smooth lava flow from a previous eruption, implying that the effusive rate at the segment midpoint has been decreasing for a long time; and (3) the smooth lava flow was erupted after the hummocky nascent ridge, burying the southern end of the ridge.

[46] Tectonic structures aid in clarifying this age relationship. A smooth lava flow on the southwestern side of the nascent ridge experienced deformation which brought $160^{\circ} \mathrm{E}$ trending structures. Meanwhile, the southernmost part of the ridge and surrounding smooth flows are equally affected by newer deformation, leading to the development of $175^{\circ} \mathrm{E}$ trending tectonic structures. This indicates that the surrounding smooth flow is older than the nascent ridge, and suggests a temporal change from smooth to hummocky flows. This was likely the result of a decrease in either eruption rate or source-lava temperature.

\section{3. "Ridge Jump" Model as a Key Factor of Asymmetric Seafloor Development}

[47] Continuous and steady symmetric seafloor accretion is expected to result in symmetry in the spacing and throw of faults on the axial valley floor [e.g., Barker and Hill, 1980]. We investigated two distinct segments in the central Mariana Basin and observed that $160^{\circ} \mathrm{E}$ structures are equally distributed within the study areas (Figures $2 \mathrm{a}$ and $3 \mathrm{a}$ ). The main structures in Seg-18 were faults and hummocks, with a large standard deviation in azimuths of faults, but no separately trending group, e.g., $175^{\circ}$ E, as in Seg-17. Simultaneously, the linear features in Seg-18 are distributed without any asymmetric features along the AVR. On the

Figure 9. (left) Close-up sonar images and (right) their phase bathymetry of Seg-17. Positions of each image are indicated in Figure 3c. Figures 9a, 9b, 9c, and 9e display seamounts. (a) Red dotted circle indicates seamounts which show a diameter $\sim 1 \mathrm{~km}$. Phase bathymetry indicates relatively flat-topped seamount surrounded by steep slope. (b) Red dotted circle indicates a crater of seamount. Blue thick arrow indicates inside of the crater that is filled by shadow on sonar image. (c) Red dotted circle indicates another flat-topped seamount surrounded by steep slope. (d) Blue arrow indicates where relative elevation of newer lava flow is countable. The elevation of difference is $\sim 15 \mathrm{~m}$. (e) (top) Side-scan sonar image and (bottom) phase bathymetry. Large $175^{\circ} \mathrm{E}$ trending features are visible on both sonar image and phase bathymetry. Red dotted circle indicates where two stacked seamounts developed. (f) Blue arrows indicate the southernmost part of the hummocky nascent ridge which developed over the smooth lava flow. Red dotted line indicates large fault which expressed contour line as a zigzag pattern on the phase bathymetry image. 
other hand, structures in Seg-17 including faults, fissures, depressions, and hummocky ridges are more complex than those of Seg-18. Thus we suggest that symmetric seafloor accretion, similar to that of a MOR, is occurring along the central Mariana Basin.

[48] The only across-axis difference we observed is the orientation of structures in Seg-17. The $\mathrm{N} 175^{\circ} \mathrm{E}$-trending tectonic structures, which are clearly oblique to the overall direction of the spreading axis, are limited to the area between the interpreted spreading axis and the eastern axial valley wall (Figure 8). Although the definitive agerelationship with $160^{\circ} \mathrm{E}$ trending features is unclear, the $175^{\circ} \mathrm{E}$ trending features are relatively newer structures, forming during the current stage of spreading (Figures $7 \mathrm{~b}, 7 \mathrm{~d}$, and 9f). The nonuniform distribution of the highly oblique features may indicate that only the eastern side of the segment is experiencing more recent deformation. Deschamps et al. [2005] demonstrated that the obliquely trending features developed along the eastern side of the valley due to local rotation of the regional stress field. The local perturbation of the stress field is due to a flexure of the bending plate close to the obliquely trending major fault that bounds the eastern axial valley of Seg-17.

[49] When we focus on the large-scale morphology of the segments, several other asymmetries are apparent, especially in Seg-17. The two off-axis peaks that bound the Seg-17 axial valley and offaxis area (Figure 1b) exhibit small asymmetries in size, height, and spacing between the interpretedspreading axis and these peaks; the western peak is higher and larger than the eastern one, with a larger spacing. The multibeam backscattering intensity over Seg-17 reveals the presence of developing volcanism in the eastern off-axis area [Deschamps et al., 2005]. This area, which is located $\sim 6 \mathrm{~km}$ from the valley axis, is characterized by higher backscattering strength relative to the axial valley floor. This high-backscattering area is consistent with a high magnetization [Deschamps et al., 2005], and therefore likely represents the most recent locus of active volcanism and seafloor accretion on the eastern off-axis area.

[50] To explain the asymmetry of the Mariana Basin, the model of ridge jump that implies volcanism and active deformation stepping eastward is preferable rather than continuous asymmetric seafloor accretion along the axis. The repetitive, small-scale (on the order of a few to several kilometers) ridge jumps may occur during basin development. The fundamental seafloor accretion system would thus be symmetric, but the smallscale ridge jumps result in an asymmetric basin. During the symmetric seafloor accretion stage, the spreading axis moved progressively westward with respect to the "fixed" active Mariana arc system. Then, the spreading axis would jump occasionally eastward and symmetric seafloor accretion would continue at the newly formed axis. The results of Iwamoto et al. [2002], who identified magnetic lineations in the central Mariana Basin, may support a "ridge jump" after a short period of symmetric seafloor accretion. Some lineations in the eastern off-axis area are less clear than those in the western off-axis area. Well recognized magnetic lineations in the western off-axis area indicate that ridge jumps did not disrupt these lineations. In contrast, less clear magnetic lineations in the eastern off-axis area may be a consequence of small ridge jumps, which may explain the asymmetric large-scale morphology. Ridge jumps disrupt preexisting seafloor by faulting, fissuring, and ensuing eruptions if dikes reach the seafloor. Such deformation makes off-axis peaks (that bound the Seg-17 axial valley and off-axis area) slightly smaller to the east than to the west, and ridge jumps make the peaks to the east slightly closer to the spreading axis. Another model proposed by Hussong and Uyeda [1982] that suggests westward displacement of arc volcanism due to overwriting of the easternmost part of the basin floor, may enhance the asymmetry.

[51] The properties of ridge jumps, such as timing, distance, and frequency, would vary among segments. The features imaged in Seg-18 indicate more symmetric seafloor accretion than those of Seg-17 do. Deschamps and Fujiwara [2003] presented magnetic anomaly data over Seg-18 and discussed high asymmetric spreading during the Brunhes-Matuyama (B-M) period, indicating that Seg-18 also exhibits asymmetry although our sonar data indicates a relatively symmetric structure. The current difference in degree of asymmetry observed over the axial valley floor of the two segments indicates that the properties of the ridge jump vary among the segments of the Mariana back-arc basin.

[52] Several causes for asymmetric seafloor accretion along the spreading ridge may be considered. The spreading axis may shift due to (1) effects of mantle flow below the spreading axis, (2) thermal effects related to active arc volcanism, or (3) heterogeneous mantle components. These mechanisms have been proposed in areas where interaction 
between hot spots and adjacent MORs induces an asymmetry in thermal or geochemical conditions across the ridge axis [e.g., Ito and Lin, 1995; Grevemeyer, 1996; Cannat et al., 1999; Goslin, 1999; Braun and Sohn, 2003], in Juan de Fuca ridge [e.g., Davis and Karsten, 1986], and in East Pacific Rise [Cormier, 1997]. Cormier [1997] mentioned asymmetric seafloor accretion along the East Pacific Rise where lateral temperature gradient or off-axis mantle heterogeneity is suspected. Rouzo et al. [1995] proposed a model for small scale convective flow beneath a spreading ridge controlling segmentation patterns and also asymmetric seafloor accretion. Mantle flow beneath back-arc basins is affected by the subducting slab [Ribe, 1989; Martinez and Taylor, 2002; Taylor and Martinez, 2003], and therefore the mantle flow might restrict the pattern of spreading ridges or seafloor accretion in back-arc settings. The active volcanic arc may act as a similar fixed heat source in the Mariana Basin, as a substitute for hot spots. All potential causes must be considered to explain the small distance of the jumps. The change of azimuth of the linear structures accompanied by the ridge jump may be important. Further investigations are needed to understand what factor(s) induce a jump, and the relationship between ridge jumps and the change in azimuths of structures in the central Mariana Basin.

\section{Conclusions}

[53] 1. We investigated two distinct spreading segments in the central Mariana Basin. Our fine-scale side-scan sonar survey indicates a variable degree of volcanism and tectonic deformation. The spreading segment "Seg-17" is currently dominated by faulting rather than volcanism, whereas the other segment "Seg-18" is currently dominated by active volcanism rather than faulting. The smooth lava flows as well as the general hourglass shape of Seg-17 suggest that a phase of robust magmatism occurred during a previous stage of spreading.

[54] 2. In Seg-17, the morphology of lava flow progressively changes from a smooth lava flow at the segment midpoint to cobbly hummocky flows toward its end. This suggests an along-axis decrease in effusion rate, probably related to magma temperature and viscosity, from the segment midpoint toward its end.

[55] 3. Faults and fissures are found within both spreading segments. In Seg-17, such tectonic features are well developed, and their azimuths are divided into two groups: parallel to $\left(160^{\circ} \mathrm{E}\right)$ and $\sim 15^{\circ}$ oblique $\left(175^{\circ} \mathrm{E}\right)$ to the overall segment trend. The obliquely trending features, such as fissures, faults, and the hummocky nascent ridge, are mainly developed in a limited area in the vicinity of the eastern wall of the axial valley.

[56] 4. Inferred from crosscutting relationship, tectonic features for both the $160^{\circ} \mathrm{E}$ and $175^{\circ} \mathrm{E}$ trending groups likely developed simultaneously with volcanic activity. The $175^{\circ} \mathrm{E}$ trending features seem younger than the parallel ones in the current stage, although definitive age relationships between the two groups are unclear.

[57] 5. The $\mathrm{N} 175^{\circ} \mathrm{E}$ trending group at Seg-17 is developed between the inferred spreading axis and its eastern margin. The nonuniform distribution of the oblique $175^{\circ} \mathrm{E}$ trending features may indicate that the eastern side of the segment is subjected to more intense deformation. As discussed by Deschamps et al. [2005] the nonuniform distribution of the obliquely trending features may be due to a local change of the regional stress field close to the obliquely trending eastern axial valley wall.

\section{Appendix A: Computing the Position of the Wadatsumi Side-Scan Sonar Vehicle}

[58] Because of problems with signal scattering, we used the super-short base line (SSBL) acousticranging system only to estimate towfish position, necessitating a towline position correction. Calculations involved (1) the ship's position and (2) heading as determined by GPS, (3) wire length, and (4) sonar vehicle depth. It was assumed that the wire was not slack, i.e., that the wire length was equal to the distance between the ship and the depressor located in front of the sonar vehicle, and that the sonar vehicle's heading was always toward the ship's stern. The ship's position and heading were recorded every $10 \mathrm{~s}$. The altitude, heading, and depth of the sonar vehicle were recorded every second. Because wire lengths for the first $1 / 3$ of the cruise were not recorded in digital files, wire lengths were estimated using the watch log every 5-15 min and interpolated.

[59] The relative distance between the sonar vehicle and the ship can be obtained through the following equation:

$$
\mathrm{D}=\mathrm{Ds}+\mathrm{Dy}+\mathrm{Lu}=\mathrm{Ls} \times \cos \theta+\sqrt{ }\left(\mathrm{L}_{\mathrm{w}}{ }^{2}-\mathrm{W}_{\mathrm{d}}{ }^{2}\right)+\mathrm{Lu}
$$

where $\mathrm{D}$ refers to the relative distance between the ship and the sonar vehicle; Ds is the along-track 
distance between the GPS antenna and the ship's stern; Dy is the projected distance between the ship's stern and the depressor; Ls refers to the longitudinal length of Ds; $\theta$ is the angle between the ship's track and the ship's heading; Lw is wire length; Wd refers to the water depth of the sonar vehicle; and $\mathrm{Lu}$ refers to the length of the umbilical cable $(50 \mathrm{~m})$ connecting the depressor and the sonar vehicle.

[60] We assumed that the wire length equals to distance between ship and depressor, although wire in seawater may slacken due to water resistance. Our calculated results produce good agreement between prominent large features such as seamounts on the multibeam bathymetry map and on our side-scan sonar imagery, suggesting that our assumptions are appropriate for sonar image interpretation.

\section{Acknowledgments}

[61] We express our appreciation to the captain and crew of $\mathrm{R} / \mathrm{V}$ Kairei as well as to the engineers and technicians, especially with respect to challenging weather conditions and serious technical problems of the Wadatsumi system. We deeply thank F. Yamamoto and G. Blackinton for their valuable help during the acquisition and processing of the data. We thank M. Coffin, K. Okino, and S. P. Obrochta for helpful discussions, and editor V. Salters and reviewers S. White, A. Briais, and K. Macdonald for thoughtful suggestions. Data corrections were applied manually using software developed by the Ocean High Technology Institute Inc. (Japan). We thank $\mathrm{H}$. Tokuyama and $\mathrm{W}$. Soh for their participation in planning the survey. The KR03-12 cruise and postcruise data processing were funded by research programs at Deep-sea Research Department, JAMSTEC and Department of Ocean Floor Geoscience, ORI. This research was partly supported by the COE program of the University of Tokyo and Sasagawa Scientific Research Grant (18-334M) from The Japan Science Society.

\section{References}

Barker, P. F., and I. A. Hill (1980), Asymmetric spreading in back-arc basins, Nature, 285, 652-654.

Bellahsen, N., J.-M. Daniel, L. Bollinger, and E. Burov (2003), Influence of viscous layers on the growth of normal faults: Insights from experimental and numerical models, J. Struct. Geol., 25, 1471-1485.

Bibee, L. D., G. G. Shor, Jr., and R. S. Lu (1980), Inter-arc spreading in the Mariana Trough, Mar. Geol., 35, 183-197.

Braun, M. G., and R. A. Sohn (2003), Melt migration in plume-ridge systems, Earth Planet. Sci. Lett., 213, 417-430.

Briais, A., H. Sloan, L. M. Parson, and B. J. Murton (2000), Accretionary process in the axial valley of the Mid-Atlantic Ridge $27 \mathrm{~N}-31 \mathrm{~N}$ from TOBI side-scan sonar images, Mar. Geophys. Res., 21, 87-119.

Cannat, M., et al. (1999), Mid-Atlantic Ridge-Azores hotspot interactions: Along-axis migration of a hotspot-derived event of enhanced magmatism 10 to $3 \mathrm{Ma}$ ago, Earth Planet. Sci. Lett., 173, 257-269.

Carbotte, S. M., R. S. Detrick, A. Harding, J. P. Canales, J. Babcock, G. Kent, E. V. Ark, M. Nedimovic, and J. Diebold (2006), Rift topography linked to magmatism at the intermediate spreading Juan de Fuca Ridge, Geology, 34, 209212.

Cormier, M.-H. (1997), The ultrafast East Pacific Rise: Instability of the plate boundary and implications for accretionary processes, Philos. Trans. R. Soc. London, Ser. A, 355, 341-367.

Davis, E. E., and J. L. Karsten (1986), On the cause of the asymmetric distribution of seamounts about the Juan de Fuca ridge: Ridge-crest migration over a heterogeneous asthenosphere, Earth Planet. Sci. Lett., 79, 385-396.

Deschamps, A., and T. Fujiwara (2003), Asymmetric accretion along the slow-spreading Mariana Ridge, Geochem. Geophys. Geosyst., 4(10), 8622, doi:10.1029/2003GC000537.

Deschamps, A., T. Fujiwara, M. Asada, P. Gente, Y. Nakamura, A. Heuret, K. Naito, H. Horikawa, and S. Suganuma (2004), Deep-tow sonar survey of the Mariana spreading axis: Initial results of the KR03-12 cruise, InterRidge News, 13, 6-9.

Deschamps, A., T. Fujiwara, M. Asada, L. Montési, and P. Gente (2005), Faulting and volcanism in the axial valley of the slow-spreading center of the Mariana back arc basin from Wadatsumi side-scan sonar images, Geochem. Geophys. Geosyst., 6, Q05006, doi:10.1029/2004GC000881.

Engels, J. L., M. H. Edwards, D. J. Fornari, M. R. Perfit, and J. R. Cann (2003), A new model for submarine volcanic collapse formation, Geochem. Geophys. Geosyst., 4(9), 1077, doi:10.1029/2002GC000483.

Fink, J. H., and R. Griffiths (1998), Morphology, eruption rates, and rheology of lava domes: Insights from laboratory models, J. Geophys. Res., 103, 527-545.

Fornari, D. J., R. M. Haymon, M. R. Perfit, T. K. P. Gregg, and M. H. Edwards (1998), Axial summit trough of the East Pacific Rise $9^{\circ}-10^{\circ} \mathrm{N}$ : Geological characteristics and evolution of the axial zone on fast spreading mid-ocean ridges, J. Geophys. Res., 103, 9827-9855.

Fryer, P. (1996), Evolution of the Mariana convergent plate margin system, Rev. Geophys., 34, 89-125.

Fujikura, K., et al. (1997), Biology and Earth scientific investigation by the submersible "Shinkai6500" system of deepsea hydrothermalism and lithosphere in the Mariana back-arc basin (in Japanese with English abstract), JAMSTEC J. Deep Sea Res., 13, 1-20.

Gamo, T., et al. (1994), Mariana 1992 diving surveys by "Shinaki 6500" (Y9204 cruise): Revisits to the MidMariana hydrothermal area and discovery of hydrothermal vents in the southern Mariana region (in Japanese with English abstract), JAMSTEC J. Deep Sea Res., 10, 153-163.

Goslin, J. (1999), Extent of Azores plume influence on the Mid-Atlantic Ridge north of the hotspot, Geology, 27, 991-994.

Gregg, T. K. P., and D. J. Fornari (1998), Long submarine lava flows: Observations and results from numerical modeling, J. Geophys. Res., 103, 27,517-27,531.

Grevemeyer, I. (1996), Hotspot-ridge interaction in the Indian Ocean: Constraints from Geosat/ERM altimetry, Geophys. J. Int., 126, 796-804.

Gribble, R. F., R. J. Stern, S. H. Bloomer, D. Stuben, T. O'Hearn, and S. Newman (1996), MORB mantle and subduction components interact to generate basalts in the southern Mariana Trough back-arc basin, Geochim. Cosmochim. Acta, 60, 2153-2166. 
Griffiths, R. W., and J. Fink (1992), Solidification and morphology of submarine lavas-A dependence on extrusion rate, J. Geophys. Res., 97, 19,729-19,737.

Hawkins, J. W., P. F. Lonsdale, J. D. Macdougall, and A. M. Volpe (1990), Petrology of the axial ridge of the Mariana Trough backarc spreading center, Earth Planet. Sci. Lett., $100,226-250$

Head, J. W., L. Wilson, and D. K. Smith (1996), Mid-ocean ridge eruptive vent morphology and substructure: Evidence for dike widths, eruption rates, and evolution of eruptions and axial volcanic ridges, J. Geophys. Res., 101, 28,26528,280 .

Hussong, D. M., and S. Uyeda (1982), Tectonic processes and the history of the Mariana Arc: A synthesis of the results of Deep Sea Drilling Project Leg 60, Initial Rep. Deep Sea Drill. Proj., 60, 909-929.

Ito, G., and J. Lin (1995), Oceanic spreading center-hotspot interactions: Constraints from along-isoclone bathymetric and gravity anomalies, Geology, 23, 657-660.

Iwamoto, H., M. Yamamoto, N. Seama, K. Kitada, T. Matsuno, Y. Nogi, T. Goto, T. Fujiwara, K. Suyehiro, and T. Yamazaki (2002), Tectonic evolution of the central Mariana Trough, Eos Trans. AGU, 83(47), Fall Meet. Suppl., Abstract T72A-1235.

Kappel, E. S., and W. B. F. Ryan (1986), Volcanic episodicity and a nonsteady rift valley along northeast Pacific spreading centers: Evidence from SeaMARC I, J. Geophys. Res., 91, $13,925-13,940$.

Karig, D. E. (1971), Origin and development of marginal basins in the western Pacific, J. Geophys. Res., 76, 24522561.

Kato, T., J. Beavan, T. Matsushima, Y. Kotake, J. T. Camacho, and S. Nakao (2003), Geodetic evidence of back-arc spreading in the Mariana Trough, Geophys. Res. Lett., 30(12), 1625, doi:10.1029/2002GL016757.

Kitada, K., N. Seama, T. Yamazaki, Y. Nogi, and K. Suyehiro (2006), Distinct regional differences in crustal thickness along the axis of the Mariana Trough, inferred from gravity anomalies, Geochem. Geophys. Geosyst., 7, Q04011, doi:10.1029/2005GC001119.

Macdonald, K. C., P. J. Fox, L. J. Perram, M. F. Eisen, R. M. Haymon, S. P. Miller, S. M. Carbotte, M.-H. Cormier, and A. N. Shor (1988), A new view of the mid-ocean ridge from the behaviour of ridge-axis discontinuities, Nature, 335, 217-225.

Martinez, F., and B. Taylor (2002), Mantle wedge control on back-arc crustal accretion, Nature, 416, 417-420.

Mastin, L. G., and D. D. Pollard (1988), Surface deformation and shallow dike intrusion processes at Inyo craters, Long Valley, California, J. Geophys. Res., 93, 13,221-13,235.
Ribe, N. M. (1989), Mantle flow induced by back arc spreading, Geophys. J. Int., 98, 85-91.

Rouzo, S., M. Rabinowicz, and A. Briais (1995), Segmentation of mid-ocean ridges with an axial valley induced by smallscale mantle convection, Nature, 374, 795-798.

Sauter, D., L. Parson, V. Mendel, C. Rommevaux-Jestin, O. Gomez, A. Briais, C. Mevel, K. Tamaki, and T. F. S. Team (2002), TOBI sidescan sonar imagery of the very slow-spreading southwest Indian Ridge: Evidence for along-axis magma distribution, Earth Planet. Sci. Lett., 199, 81-95.

Seama, N., T. Yamazaki, H. Iwamoto, K. Kitada, M. Yamamoto, T. Fujiwara, Y. Nogi, K. Okino, and K. Suyehiro (2002), Tectonic features of the Mariana Trough, Eos Trans. AGU, 83(47), Fall Meet. Suppl., Abstract T71F-08.

Smith, D. K., and J. R. Cann (1992), The role of seamount volcanism in crustal construction at the Mid-Atlantic Ridge $\left(24^{\circ}-30^{\circ} \mathrm{N}\right)$, J. Geophys. Res., 97, 1645-1658.

Smith, D. K., J. Cann, M. E. Dougherty, J. Lin, S. Spencer, C. Macleod, J. Keeton, E. Mcallister, B. Brooks, R. Pascoe, and W. Robertson (1995), Mid-Atlantic Ridge volcanism from deep-towed side-scan sonar images, $25^{\circ}-29^{\circ} \mathrm{N}, J$. Volcanol. Geotherm. Res., 67, 233-262.

Smith, W. H. F., and D. T. Sandwell (1997), Global sea floor topography from satellite altimetry and ship depth soundings, Science, 277, 1956-1962.

Stakes, D. S., J. W. Shervais, and C. A. Hopson (1984), The volcanic-tectonic cycle of the FAMOUS and AMAR valleys, Mid-Atlantic Ridge $\left(36^{\circ} 47^{\prime} \mathrm{N}\right)$ : Evidence from basalt glass and phenocryst compositional variations for a steady state magma chamber beneath the valley midsections, AMAR 3, J. Geophys. Res., 89, 6995-7028.

Taylor, B., and F. Martinez (2003), Back-arc basin basalt systematics, Earth Planet. Sci. Lett., 210, 481-497.

White, S. M., K. C. Macdonald, and R. M. Haymon (2000), Basalticlava domes, lava lakes, and volcanic segmentation on the southern East Pacific Rise, J. Geophys. Res., 105, 23,519-23,536.

White, S. M., R. M. Haymon, D. J. Fornari, M. R. Perfit, and K. C. Macdonald (2002), Correlation between volcanic and tectonic segmentation of fast-spreading ridges: Evidence from volcanic structures and lava flow morphology on the East Pacific Rise at $9^{\circ}-10^{\circ} \mathrm{N}$, J. Geophys. Res., 107(B8), 2173, doi:10.1029/2001JB000571

Yamazaki, T., F. Murakami, and E. Saito (1993), Mode of seafloor spreading in the northern Mariana Trough, Tectonophysics, 221, 207-222.

Yamazaki, T., N. Seama, K. Okino, K. Kitada, M. Joshima, H. Oda, and J. Naka (2003), Spreading process of the northern Mariana Trough: Rifting-spreading transition at $22^{\circ} \mathrm{N}$, Geochem. Geophys. Geosyst., 4(9), 1075, doi:10.1029/2002GC000492. 